\title{
Highly efficient stereoconservative syntheses of new, bifunctional atropisomeric organocatalysts
}

\author{
Ferenc Faigl, ${ }^{a, b *}$ Zsuzsa Erdélyi, $^{a}$ Tamás Holzbauer, ${ }^{c}$ and Béla Mátravölgyi ${ }^{b}$ \\ ${ }^{a}$ Department of Organic Chemistry and Technology, Budapest University of Technology \\ and Economics, H 1111 Budapest, Budafoki út 8, Hungary \\ ${ }^{b}$ MTA BME Organic Chemical Technology Research Group, Hungarian Academy of Sciences, \\ H 1111 Budapest, Budafoki út 8, Hungary \\ ${ }^{c}$ Research Centre of Natural Sciences, Hungarian Academy of Sciences, \\ H-1117 Budapest, Magyar tudósok körútja 2, Hungary \\ E-mail:ffaigl@mail.bme.hu
}

DOI: $\underline{\text { http://dx.doi.org/10.3998/ark.5550190.p009.505 }}$

\begin{abstract}
The first synthesis of new organocatalysts with 1-phenylpyrrole atropisomeric skeleton containing a thiourea group is reported. A possible structural reason for the stereochemical lability of an atropisomeric intermediate is described together with a way to preserve the isomeric purity during the synthesis. The catalytic activities of the new atropisomeric organocatalysts have been tested in Michael addition reactions.
\end{abstract}

Keywords: Stereoconservative synthesis, atropisomers, 1-arylpyrroles, thiocarbamides, organocatalysts

\section{Introduction}

The application of chiral bifunctional urea and thiourea derivatives as enantioselective organocatalysts to the synthesis of optically active compounds has recently appeared as a new and exciting area of contemporary synthetic organic chemistry. ${ }^{1,2}$ The observed good stereocontrol achieved by the chiral bifunctional catalysts is due to concomitant and synergistic activation of both reacting partners during $\mathrm{C}-\mathrm{C}$ bond formation.

Among the first examples, Jacobsen and co-workers have shown that chiral thiourea based catalysts can successfully be used in the asymmetric cyanation reaction of aldimines. ${ }^{3-5}$ Since then numerous bifunctional tertiary amine-thiourea organocatalysts have been published. ${ }^{6-13}$

Despite their great utility, these catalysts are derived from a very limited range of chiral structural scaffolds, including cyclohexane-1,2-diamine, cinchona alkaloids and amino acid derivatives, which could easily be reduced to $\beta$-amino alcohols. ${ }^{14-18}$ 
Furthermore, only few examples are known in which the thiourea and the amino groups are connected to an atropisomeric skeleton within the organocatalyst molecule. The 1,1'-binaphthyl2,2'-diamine scaffold was applied first by $\mathrm{Wang}^{19}$ in enantioselective Baylis-Hillman reactions and later on by Melchiorre and co-workers ${ }^{20}$ for the enantioselective addition of 3methyloxindole to cinnamaldehyde. The same atropisomeric skeleton was used by Barbas and co-workers, ${ }^{21}$ who connected an additional chiral alkaloid moiety to the other side of the thiourea and applied this novel multifunctional organocatalyst for enantioselective cascade reactions. The binaphthalene based organocatalysts contain quite rigid structures and similar rigidity can be recognized in many alkaloid-based thiourea catalysts. However, other authors have demonstrated the advantage of conformational flexibility of guanidine/bisthiourea organocatalysts in substrate activation and chiral induction during phase transfer catalytic processes. ${ }^{22}$

Bifunctional organocatalysts are frequently tested in enantioselective Michael addition of $\beta$ nitrostyrene to 1,3-dialkyl- and 1,3-diaryl-1,3-propanediones. Dibenzoylmethane is normally not considered as a good Michael donor due to the steric hindrance of the two aryl groups and usually requires harsh reaction conditions and long reaction times. In previous reports several new bifunctional organocatalysts were described which efficiently accelerated the Michael reaction of dibenzoylmethane. Structures and efficiencies of those organocatalysts are depicted in Scheme 1. ${ }^{23-27}$ Wang et al. applied a trans-1,2-diaminocyclohexane based thiourea as the organocatalyst with good selectivities. ${ }^{23}$ Malerich et al. combined first a chincona alkaloid moiety with a squaramide derivative. ${ }^{24}$ They took advantages of the higher diastance between the two H-bridge forming NH groups in the squaramide compared to the same distance in thiourea. The above mentioned Michael reaction was accomplished in the presence of $0.5 \mathrm{~mol} \%$ catalyst with excellent yield and good selectivity. In the same reaction Tan et al. applied 9-aminoquinine as organocatalyst with higher selectivity, however complete conversion required as much as 15 mol \% catalyst loading. ${ }^{25}$ Liu et al. synthesized the chiral cinchona alkaloid connected squaramide instead of thiourea and the axially chiral 2,2'-dihydroxy-1,1'-binaphtalene moiety was coupled to the second amino group of the squaramide. This modification resulted in a highly efficient organocatalyst, but reaction of dibenzoylmethane with $\beta$-nitrostyrene was much slower $(36 \mathrm{~h}) .{ }^{26}$ Isik et al. published a new squaramide type organocatalyst with a more simple structure than the previously mentioned one. ${ }^{27}$ The authors coupled the strongly basic 4dimethylaminopyridine moiety to the first amino group of trans-1,2-diaminocyclohexane, while the other amino group was connected to the adamantyl group containing squaramide. Addition of $\beta$-nitrostyrene to dibenzoylmethane was complete within 5 hours in the presence of $1 \mathrm{~mol} \%$ of that catalyst and the product was isolated with high yield and ee. 


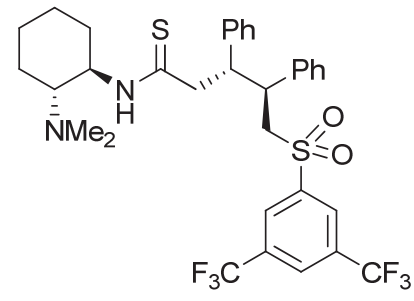

Wang et al. (ref. 23)

$5 \mathrm{~mol} \%$ cat., $12 \mathrm{~h}$ $95 \%$ yield, $85 \%$ ee

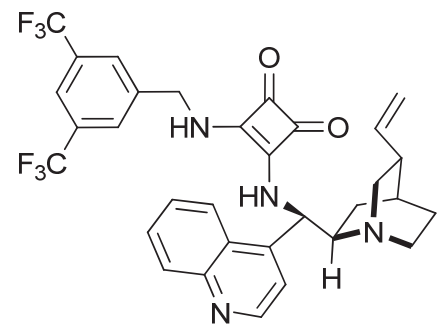

Malerich et al. (ref. 24)

$0.5 \mathrm{~mol} \%$ cat., $24 \mathrm{~h}$ $93 \%$ yield, $88 \%$ ee

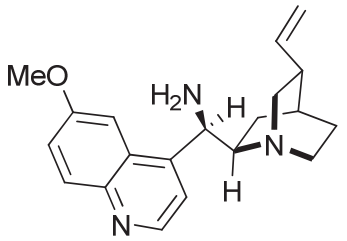

Tan et al. (ref. 25)

$15 \mathrm{~mol} \%$ cat., $8 \mathrm{~h}$ $96 \%$ yield, $98 \%$ ee
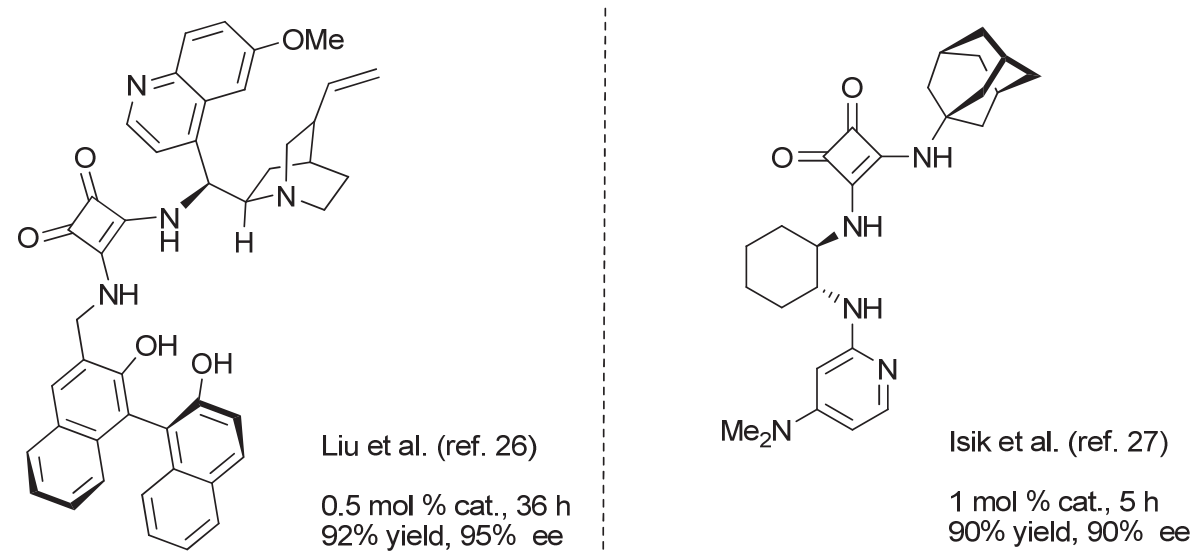

Scheme 1. Examples of reported chiral bifunctional organocatalysts of Michael addition.

Recently, a series of new atropisomeric 1-arylpyrrole based amino alcohols have been prepared in our laboratory and their excellent chiral inductive capabilities have been demonstrated in the enantioselective addition of diethylzinc to aldehydes. ${ }^{28-30}$ We envisaged the combination of the atropisomeric 1-phenylpyrrole structure with thiourea and tertiary amine functions in one molecule to provide a new class of bifunctional organocatalyst having the potential to produce a synergistic effect in asymmetric transformations. Two types of organocatalyst were designed: a series with a direct connection between the thiourea moiety and the benzene ring of the biaryl skeleton (type 1, Scheme 2) to produce a relatively rigid structure, and another in which a methylene group is inserted between the thiourea function and the atropisomeric aromatic skeleton (type 2). The latter compounds are conformationally more flexible than those of type $\mathbf{1}$, and so we could compare the effect of this structural difference on the catalytic activity and asymmetric induction ability of these new organocatalysts.

We now report an efficient synthesis of these new atropisomeric bifunctional thiourea type organocatalysts, and their performance in two model reactions: the Michael additions of acetylacetone and dibenzoylmethane to $(E)-\beta$-nitrostyrene. 


\section{Results and Discussion}

Modification of the pyrrole- and the benzene-ring-connected $\alpha$ - and/or ortho-substituents is always challenging because the rotational barrier around the $\mathrm{C}-\mathrm{N}$ bond strongly depends on the structure and possible chemical interactions of these "percussive" groups. Unexpected racemization during chemical transformations of these substituents of atropisomeric 1-phenylpyrrole derivatives has been observed by our group. ${ }^{31-34}$ Therefore careful selection of the applied reactions and stepwise control of the ee values of each intermediates were important during the development of the stereoconservative syntheses of the designed new bifunctional atropisomeric 1-phenylpyrrole derivatives $\left(\left(R_{\mathrm{a}}\right)\right.$-1a-f and $\left(S_{\mathrm{a}}\right) \mathbf{- 2 a}, \mathbf{b}$, Scheme 2$)$.<smiles>CN(C)Cc1cccn1-c1c(NC(=S)Nc2cc(C(F)(F)F)cc(C(F)(F)F)c2)cccc1C(F)(F)F</smiles>

$\left(R_{\mathrm{a}}\right)-1 \mathrm{a}$<smiles>FC(F)(F)c1cc(NC(=S)Nc2cccc(C(F)(F)F)c2-n2cccc2CN2CCCC2)cc(C(F)(F)F)c1</smiles>

$\left(R_{\mathrm{a}}\right)-1 \mathrm{~d}$

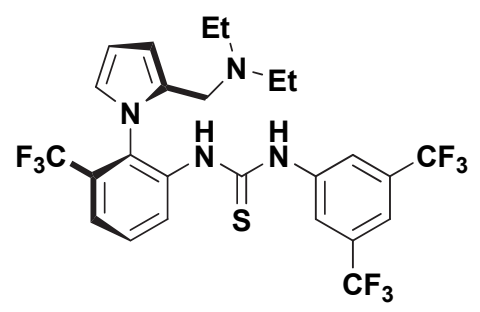

$\left(R_{\mathrm{a}}\right)-\mathbf{1 b}$

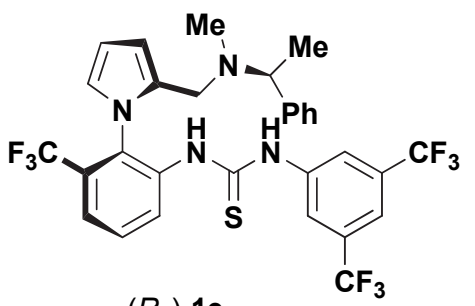

$\left(R_{\mathrm{a}}\right)-1 \mathrm{e}$<smiles>CC(C)(C)N(Cc1ccccc1)Cc1cccn1-c1c(NC(=S)Nc2cc(C(F)(F)F)cc(C(F)(F)F)c2)cccc1C(F)(F)F</smiles>

$\left(R_{\mathrm{a}}\right)-1 \mathrm{c}$

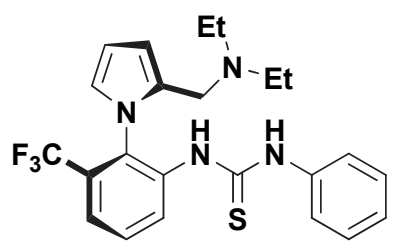

$\left(R_{\mathrm{a}}\right)-1 \mathrm{f}$

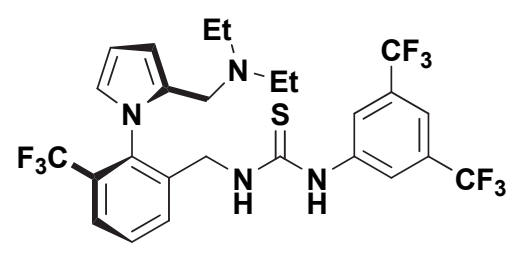

$\left(S_{\mathrm{a}}\right)-2 \mathrm{a}$

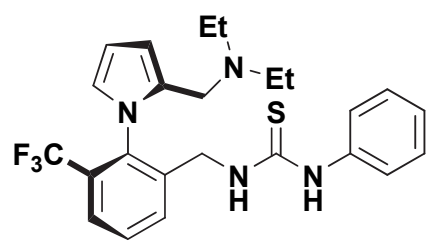

$\left(S_{a}\right)-\mathbf{2 b}$

Scheme 2. Structures of the designed new organocatalysts $\left(R_{\mathrm{a}}\right)-\mathbf{1 a} \mathbf{a}-\mathbf{f}$ and $\left(S_{\mathrm{a}}\right)-\mathbf{2 a}, \mathbf{b}$.

Both types of target compounds were prepared from the optically active 1-(2-carboxy-6trifluoromethylphenyl)pyrrole-2-carboxylic acid $\left(\left(S_{\mathrm{a}}\right)-3\right.$, Scheme 3$)$ as starting material.

The synthesis and optical resolution of $( \pm)-3$ with methyl phenylglycinate $(\mathrm{PhGMe})$ and selective monoesterification of $\left(S_{\mathrm{a}}\right)$-3 were accomplished according to literature procedures (Scheme 2). ${ }^{31,32}$ Chemoselectivity of the $\left(S_{\mathrm{a}}\right)-\mathbf{4}$ ester-forming reaction is due to the significant difference between the reactivity of the two carboxylic groups in $\left(S_{\mathrm{a}}\right)-\mathbf{3}$. Then, preparation of $\left(R_{\mathrm{a}}\right)$-8a-e was continued by analogy to our previously developed series of reactions. ${ }^{33}$ Thus the 
carboxylic function connected to the pyrrole ring was transformed into different acid amides $\left(\left(S_{\mathrm{a}}\right)\right.$-5a-e) in two steps. Even when the acid chloride formation was carried out at $80{ }^{\circ} \mathrm{C}$ for 2 hours in toluene followed by the addition of the different amines at $0{ }^{\circ} \mathrm{C}$, no racemization was observed. Each amide $\left(\left(S_{\mathrm{a}}\right)\right.$-5a-e) was isolated in enantiopure form (ee $\left.>99 \%\right)$. Then the ester function connected to the benzene ring was hydrolysed using sodium hydroxide at ambient temperature. This hydrolysis is quite slow (1-7 days) but the chemo- and stereo-selectivities were perfect in each case. Transformation of the free carboxylic function in $\left(S_{\mathrm{a}}\right)$-6a-e into a primary amine group was accomplished using diphenylphosphoryl azide (DPPA). This method provided the atropisomeric aniline derivatives $\left(\left(R_{\mathrm{a}}\right)-\mathbf{7 a}-\mathbf{e}\right)$ without any racemization. The intermediates containing tertiary amine functions $\left(\left(R_{a}\right)\right.$-8a-e $)$ were obtained using the borane-dimethyl sulfide complex because application of a more reactive reducing agent like lithium aluminium hydride could partially defluorinate the trifluoromethyl groups of the molecules. Reduction of the deactivated pyrrole carbonyl group required prolonged reaction time ( 2 days) at $60{ }^{\circ} \mathrm{C}$ but each acid amide could be transformed into the tertiary amine derivative without any racemization. Finally the thiourea function was constructed using the corresponding aryl isothiocyanates. The products $\left(\left(R_{\mathrm{a}}\right)-\mathbf{1 a - f}\right)$ were purified by flash chromatography. Each compound was obtained in enantiomerically pure form (ee $>99 \%$, HPLC).

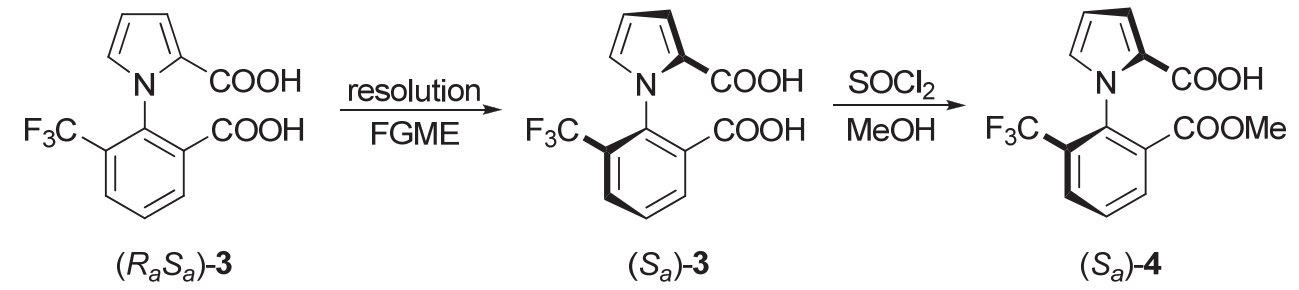

$\left(R_{a} S_{a}\right)-3 \quad\left(S_{a}\right)-3$

1. $\mathrm{SOCl}_{2}$ 2. $\mathrm{R}^{1} \mathrm{R}^{2} \mathrm{NH}$

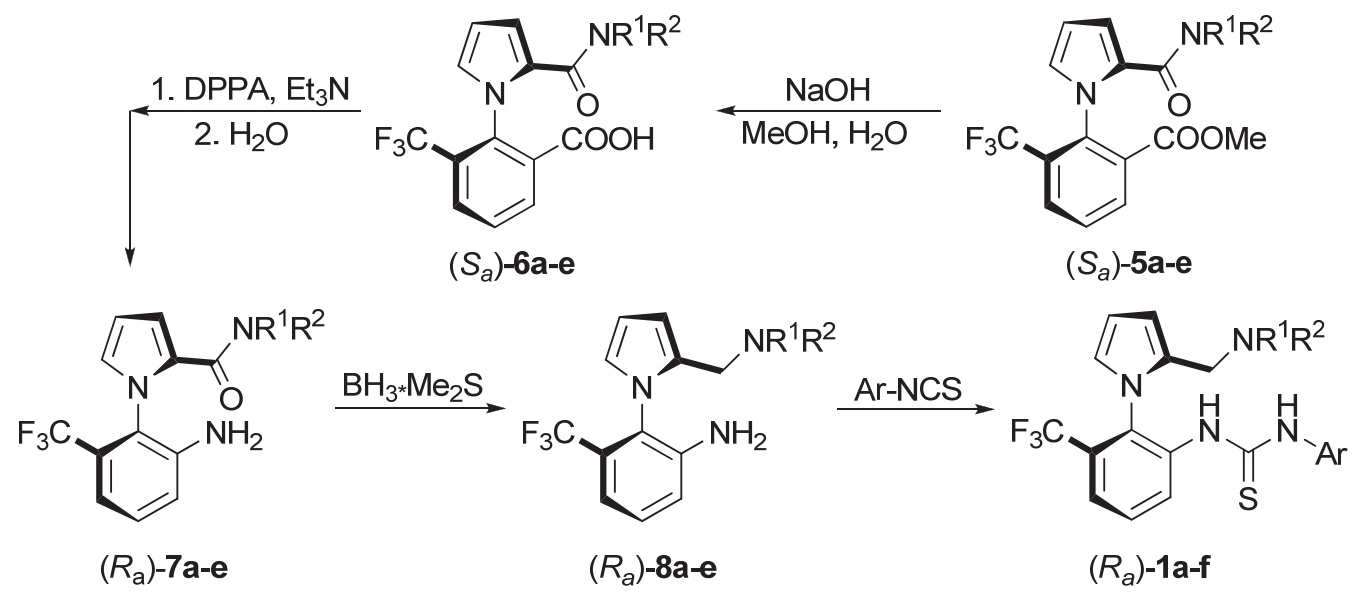

Scheme 3. Synthesis of compounds $\left(S_{\mathrm{a}}\right)$-1a-f $\left(\mathbf{a}: \mathrm{R}^{1}=\mathrm{R}^{2}=\mathrm{Me}, \mathrm{Ar}=3,5\right.$-bis(trifluoromethyl)phenyl; b: $\mathrm{R}^{1}=\mathrm{R}^{2}=\mathrm{Et}, \mathrm{Ar}=3,5$-bis(trifluoromethyl)phenyl; $\mathbf{c}: \mathrm{R}^{1}=\mathrm{R}^{2}=\mathrm{Bu}, \mathrm{Ar}=3,5$-bis(trifluoromethyl) phenyl; d: $\mathrm{NR}^{1} \mathrm{R}^{2}=$ pyrrolidin-1-yl, Ar=3,5-bis(trifluoromethyl)phenyl; $\mathbf{e}: \mathrm{R}^{1}=\mathrm{Me}, \mathrm{R}^{2}=(S)-1$ methylbenzyl, Ar=3,5-bis(trifluoromethyl)phenyl; $\mathbf{f}: \mathrm{R}^{1}=\mathrm{R}^{2}=\mathrm{Et}, \mathrm{Ar}=$ phenyl). 
The same dicarboxylic acid (( \pm )-3) was used as starting material for the preparation of compounds $\left(S_{\mathrm{a}}\right)$-2a $\mathbf{a}, \mathbf{b}$, and $\left(S_{\mathrm{a}}\right) \mathbf{- 4},\left(S_{\mathrm{a}}\right)-\mathbf{5 b}$ and $\left(S_{\mathrm{a}}\right)$-6b were also the isolated intermediates of this synthesis (Scheme 3).

In order to find a shorter route to compounds $\left(S_{\mathrm{a}}\right)$-2a and $\left(S_{\mathrm{a}}\right) \mathbf{- 2} \mathbf{b}$, transformation of the carboxylic group of $\left(S_{\mathrm{a}}\right)$-6b into the primary amide function in compound (10) was also accomplished in two steps (Scheme 3) via the corresponding acid chloride. The two amide functions in compound $\mathbf{1 0}$ could be reduced in one pot with the borane complex and one could avoid the use of hydrazine hydrate as well. However, starting from optically pure $\left(S_{\mathrm{a}}\right)-\mathbf{6 b}$ we obtained a practically racemic diamide (10, Scheme 4$)$.

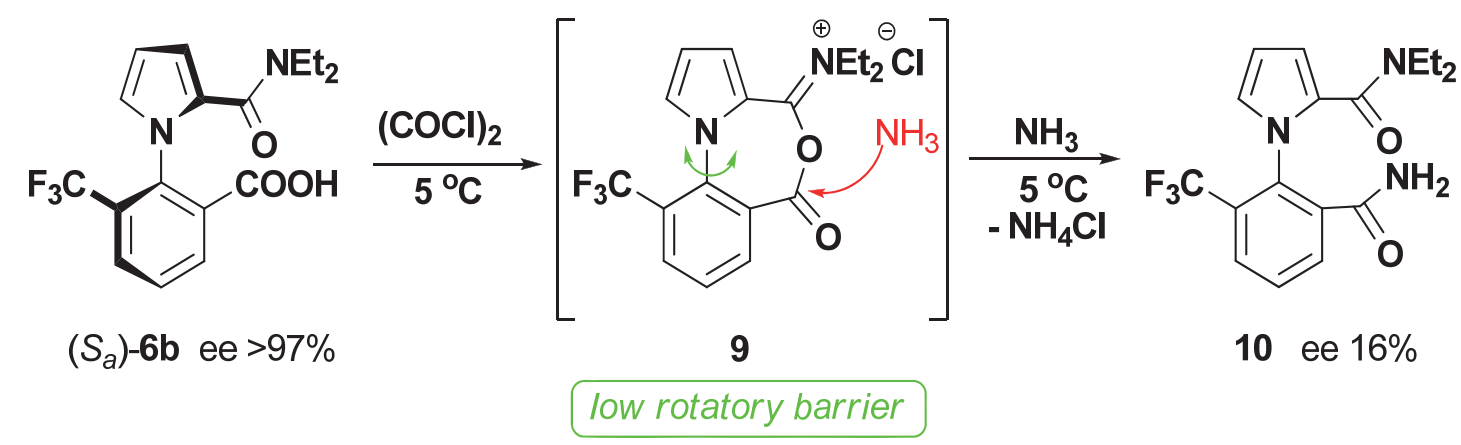

Scheme 4. Proposed mechanism of the racemization during acid amide formation.

It may be recalled that racemization was also observed during esterification of $\left(S_{\mathrm{a}}\right)-\mathbf{6 b}$ in methanol with thionyl chloride. ${ }^{33}$ On the other hand we have described high conformational stabilities of numerous $\alpha, o, o^{\prime}$-trisubstituted 1-phenylpyrrole type atropisomers, ${ }^{28-34}$ and stereochemical lability was observed only in the cases where a tricyclic intermediate with a low rotational barrier (such as 9, Scheme 4) could be formed during the modification of the substituents. Therefore we suppose that during the formation of the diamide 10, the activated acyl group of compound $\left(S_{\mathrm{a}}\right)$-6b may react with the electron-rich amide function situated in the pyrrole $\alpha$-position, providing an isoimidium salt (9) which is quite similar to several known compounds, ${ }^{35,36}$ and the formation of this stereochemically labile tricyclic intermediate might be responsible for the racemization. The molecular structure of $\left(S_{\mathrm{a}}\right)$-6b (Figure 1) based on single crystal X-ray diffraction measurements confirms the possibility of the steric arrangement of 9; the proximity of the benzene-connected carboxylic group and the carbonyl oxygen atom of the pyrrole-connected diethylamido group can be seen in this structure.

In order to avoid racemization, another strategy was applied for the preparation of enantiomerically pure $\left(S_{\mathrm{a}}\right)$-2a and $\left(S_{\mathrm{a}}\right)$-2b (Scheme 5). First, selective reduction of the methoxycarbonyl group of $\left(S_{\mathrm{a}}\right)$-5 $\mathbf{b}$ was carried out with an excess of sodium borohydride while the less reactive diethylamide group remained intact. The primary hydroxyl group of $\left(S_{\mathrm{a}}\right)$-11 was transformed into a primary amine function in three steps using the well-known Gabriel synthesis protocol (intermediate $\left(S_{\mathrm{a}}\right)$-12). Then the amide group of compound $\left(S_{\mathrm{a}}\right)$-13 was reduced with 
borane-dimethyl sulfide complex. Finally the products $\left(S_{\mathrm{a}}\right) \mathbf{- 2 a}, \mathbf{b}$ were obtained by the addition of the corresponding aryl isothiocyanate to the amine $\left(S_{\mathrm{a}}\right)-\mathbf{1 4}$. This procedure provided compounds $\left(S_{\mathrm{a}}\right)$-2a and $\left(S_{\mathrm{a}}\right)$-2b in enantiomerically pure form (ee $>99 \%$, HPLC).

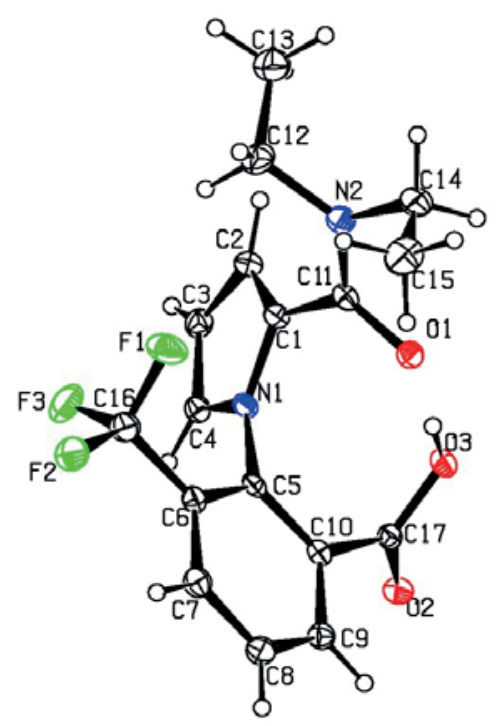

Figure 1. The crystallographically independent molecule in the asymmetric unit of the crystal $\left(S_{\mathrm{a}}\right)$-6b with the atomic labelling. Displacement ellipsoids are drawn at the $30 \%$ probability level (C - black, N - blue, O - red, F - green and H - white).<smiles>CCNC(=O)c1cccn1-c1c(C(=O)N2C(=O)c3ccccc3C2=O)cccc1C(F)(F)F</smiles>

$\mathrm{NH}_{2}-\mathrm{NH}_{2} \cdot \mathrm{H}_{2} \mathrm{O} \downarrow$<smiles>CCNCc1cccn1-c1c(CNC(=S)N[Al])cccc1C(F)(F)F</smiles>

$\left(S_{a}\right)-\mathbf{2 a}, \mathbf{b}$<smiles>CCNCc1cccn1-c1c(CN)cccc1C(F)(F)F</smiles>

$\left(S_{a}\right)-14$<smiles>CCNC(=O)c1cccn1-c1c(CN)cccc1C(F)(F)F</smiles>

$\left(S_{a}\right)-13$

Scheme 5. Synthesis of compounds $\left(S_{\mathrm{a}}\right)-\mathbf{2 a}, \mathbf{b}\left(\mathbf{a}: \mathrm{R}^{1}=\mathrm{R}^{2}=\mathrm{Et}, \mathrm{Ar}=3,5\right.$-bis(trifluoromethyl)phenyl; b: $\mathrm{R}^{1}=\mathrm{R}^{2}=\mathrm{Et}, \mathrm{Ar}=$ phenyl). 
The catalytic activities of the new bifunctional atropisomeric compounds $\left(\left(R_{\mathrm{a}}\right)-\mathbf{1 a}-\mathbf{f}\right.$ and $\left(S_{\mathrm{a}}\right)$ 2a,b) were tested in two Michael addition reactions. In the first run $\beta$-nitrostyrene (15) was reacted with dibenzoylmethane (16) in the presence of $5 \mathrm{~mol} \%$ of $\left(R_{\mathrm{a}}\right)-\mathbf{1 b}$. The reactions were carried out in different solvents at different temperatures and the yield and ee of product $\mathbf{1 7}$ were determined by HPLC measurements (Scheme 6, Table 1).

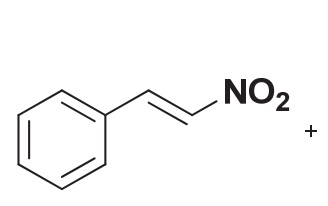

15

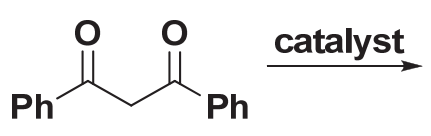

16<smiles>O=C(c1ccccc1)C(C(=O)[C@H](C[N+](=O)[O-])c1ccccc1)c1ccccc1</smiles>

17

Scheme 6. Addition of $\mathbf{1 6}$ to $\mathbf{1 5}$ in the presence of catalysts $\left(R_{\mathrm{a}}\right)-\mathbf{1 a}-\mathbf{f}$ and $\left(S_{\mathrm{a}}\right)-\mathbf{2 a}, \mathbf{b}$.

The best ee values were achieved in toluene at about $10-15{ }^{\circ} \mathrm{C}$, and therefore the activities of

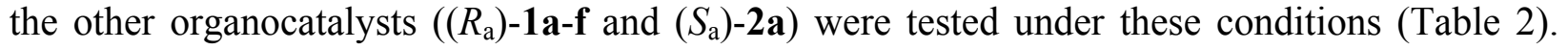
Although it was found that $\left(S_{\mathrm{a}}\right)$-2a is the most efficient catalyst for the addition ( $97 \%$ yield), no asymmetric induction was observed in its use. Compound $\left(S_{a}\right)$-2b was less effective as a catalyst than $\left(S_{\mathrm{a}}\right)-\mathbf{2 a}$, therefore it is not mentioned in Table 2.

Table 1. Solvent and temperature effects on the formation of $\mathbf{1 7}$ in the presence of $\left(R_{\mathrm{a}}\right)-\mathbf{1 b}$

\begin{tabular}{cccc}
\hline \multirow{2}{*}{ Solvent } & Temperature $\left({ }^{\circ} \mathrm{C}\right)$ & \multicolumn{2}{c}{ Product $^{\mathbf{1 7}}{ }^{a}$} \\
\cline { 3 - 4 } & & yield $^{b}(\%)$ & $e e^{b}(\mathbf{\%})$ \\
\hline Dichloromethane & 15 & 11 & 37 \\
Diethyl ether & 15 & 5 & 49 \\
Hexane & 15 & 4 & 38 \\
Dimethylformamide & 15 & 5 & 2 \\
Ethyl acetate & 15 & 4 & 45 \\
Toluene & 15 & 17 & 48 \\
Toluene & 0 & 13 & 49 \\
Toluene & 10 & 17 & 49 \\
Toluene & 15 & 17 & 48 \\
Toluene & 18 & 23 & 47 \\
Toluene & 20 & 30 & 44 \\
Toluene & 22 & 17 & 42 \\
Toluene & 28 & 17 & 42 \\
\hline
\end{tabular}

${ }^{a}$ Reactions were accomplished in the presence of $5 \mathrm{~mol} \%$ of $\mathbf{1 b}$ catalyst, 7 days reaction time. ${ }^{b}$ Yields and ee values were determined from the crude reaction mixture by HPLC measurements using Phenomenex Lux Cellulose-1 column. 
In the presence of the more rigid $\left(R_{a}\right)$-1 type catalysts each reaction proceeded slower than in the presence of $\left(S_{\mathrm{a}}\right)$-2a and a small to medium level of asymmetric inductions were observed. In this respect $\left(R_{\mathrm{a}}\right) \mathbf{- 1 b}$ seems to be the best among the investigated compounds. Therefore this compound was used to investigate the effect of catalyst concentration. Experimental data showed (Table 2) significant increase of the yield when the amount of $\left(R_{\mathrm{a}}\right)-\mathbf{1 b}$ was set up from $1 \mathrm{~mol} \%$ to 5 and $10 \mathrm{~mol} \%$, respectively. In the same time the ee of the product slightly decreased. These observations indicate self association of $\left(R_{\mathrm{a}}\right)$-1 $\mathbf{b}$ in higher concentrations in toluene.

The catalyst associations may serve as more active species in the reactions, but at the same time the greater freedom of connections among the catalyst associations and the two reactants may cause a decrease in the asymmetric induction effect of the catalyst. This phenomenon is known among other thiourea-type organocatalysts too. ${ }^{37,38}$

Table 2. Effects of structure and amounts of catalyst on the formation of compound $\mathbf{1 7}$

\begin{tabular}{|c|c|c|c|}
\hline \multirow[t]{2}{*}{ Catalyst } & \multirow{2}{*}{$\begin{array}{l}\text { Amount of catalyst } \\
(\mathrm{mol} \%)\end{array}$} & \multicolumn{2}{|c|}{ Product $\mathbf{1 7}^{a}$} \\
\hline & & yield $^{b}(\%)$ & $e e^{b}(\%)$ \\
\hline$\left(S_{\mathrm{a}}\right)-\mathbf{1 a}$ & 5 & 46 & 11 \\
\hline$\left(S_{\mathrm{a}}\right)-\mathbf{1 b}$ & 1 & 4 & 54 \\
\hline$\left(S_{\mathrm{a}}\right) \mathbf{- 1 \mathbf { b }}$ & 5 & 17 & 49 \\
\hline$\left(S_{\mathrm{a}}\right)-\mathbf{1 b}$ & 10 & 39 & 40 \\
\hline$\left(S_{\mathrm{a}}\right)-\mathbf{1 c}$ & 5 & 37 & 15 \\
\hline$\left(S_{\mathrm{a}}\right)-\mathbf{1 d}$ & 5 & 37 & 25 \\
\hline$\left(S_{\mathrm{a}}\right)-\mathbf{1 e}$ & 5 & 6 & 9 \\
\hline$\left(S_{\mathrm{a}}\right) \mathbf{- 1 f}$ & 5 & 5 & 30 \\
\hline$\left(S_{\mathrm{a}}\right)-\mathbf{2} \mathbf{a}$ & 5 & 97 & 0 \\
\hline
\end{tabular}

${ }^{a}$ Reactions were accomplished in toluene during 7 days, in the presence of $5 \mathrm{~mol} \%$ catalyst, at $10{ }^{\circ} \mathrm{C}$.

${ }^{b}$ Yields and ee values were determined from the crude reaction mixture by HPLC measurements using Phenomenex Lux Cellulose-1 column.

Catalytic activities of compounds $\left(R_{\mathrm{a}}\right)$-1a-e and $\left(S_{\mathrm{a}}\right)$-2a, $\mathbf{b}$ were also investigated in the reaction of $\beta$-nitrostyrene (15) and acetylacetone (18). Each reaction was carried out in the presence of $5 \mathrm{~mol} \%$ catalyst in toluene at $10^{\circ} \mathrm{C}$ (Scheme 7).

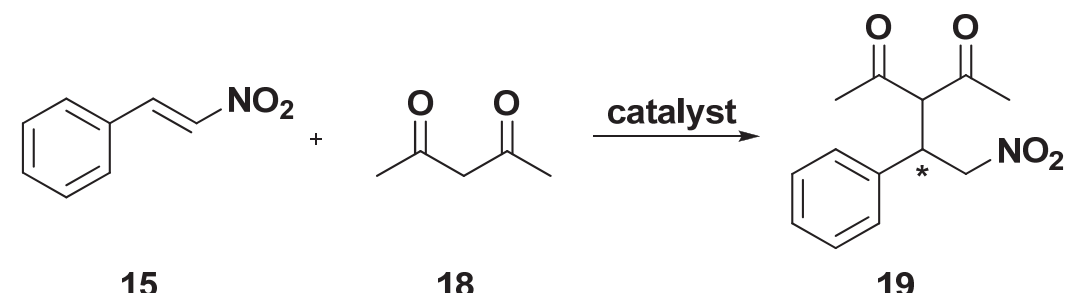

Scheme 7. Addition of $\mathbf{1 8}$ to $\mathbf{1 5}$ in the presence of catalysts $\left(R_{\mathrm{a}}\right)-\mathbf{1 a}-\mathbf{f}$ and $\left(S_{\mathrm{a}}\right)-\mathbf{2} \mathbf{a}, \mathbf{b}$. 
The experimental results are collected in Table 3. Regarding the product formation (yields of 19 within the same reaction time), $\left(R_{a}\right)$-1 type catalysts worked slower than the more flexible $\left(S_{\mathrm{a}}\right)$-2a which showed the same high activity (95\% yield) as in the previous test reaction. Catalyst $\left(R_{\mathrm{a}}\right)$-1b provided much lower yields and ee in this case, and the best asymmetric inductions were observed using $\left(R_{\mathrm{a}}\right)$-1d and $\left(S_{\mathrm{a}}\right)$-2a.

Table 3. Effect of the catalyst structure on the enantioselective formation of $\mathbf{1 9}$

\begin{tabular}{|c|c|c|}
\hline \multirow{2}{*}{ Catalyst } & \multicolumn{2}{|c|}{ Product $\mathbf{1 9}^{a}$} \\
\hline & $\operatorname{yield}^{b}(\%)$ & $e e^{b}(\%)$ \\
\hline$\left(R_{a}\right)-\mathbf{1 a}$ & 34 & 5 \\
\hline$\left(R_{a}\right)-\mathbf{1 b}$ & 15 & 16 \\
\hline$\left(R_{a}\right)-1 \mathrm{c}$ & 20 & 4 \\
\hline$\left(R_{a}\right)-\mathbf{1 d}$ & 32 & 17 \\
\hline$\left(R_{a}\right)-\mathbf{1 e}$ & 8 & 26 \\
\hline$\left(S_{a}\right)-\mathbf{2} \mathbf{a}$ & 95 & 25 \\
\hline$\left(S_{a}\right)-\mathbf{2} \mathbf{b}^{\mathrm{c}}$ & 96 & 6 \\
\hline$\left(S_{a}\right)-\mathbf{2} \mathbf{b}^{\mathrm{c}}$ & 95 & 3 \\
\hline
\end{tabular}

${ }^{a}$ Each reaction was carried out in toluene over 7 days, in the presence of $5 \mathrm{~mol} \%$ catalyst, at $10{ }^{\circ} \mathrm{C}$. ${ }^{b}$ Yields and ee values were determined from the crude reaction mixture by HPLC measurements using Phenomenex Lux Cellulose-1 column. ${ }^{c}$ Reactions were conducted at $24{ }^{\circ} \mathrm{C}$.

\section{Conclusions}

Efficient syntheses of new 1-phenylpyrrole type organocatalysts containing thiourea and tertiary amino groups have been developed. Compounds $\left(R_{\mathrm{a}}\right)$-1a-f could be prepared without any racemization. Loss of the conformational stability towards certain chemical transformations of the percussive groups was observed during preparation of $\left(S_{\mathrm{a}}\right) \mathbf{- 2} \mathbf{a}$ and $\left(S_{\mathrm{a}}\right) \mathbf{- 2} \mathbf{b}$, which could be explained by the formation of a tricyclic intermediate (9) because of the presence of an activated acyl group which is able to attack the pyrrole-connected amido group. This observation led us to find another stereoconservative route to the target compounds $\left(S_{\mathrm{a}}\right) \mathbf{- 2} \mathbf{a}, \mathbf{b}$. The synthesized new atropisomeric compounds were successfully tested as organocatalysts. The experimental results of the Michael addition reactions served as proof of concept: compounds $\left(R_{\mathrm{a}}\right) \mathbf{- 1} \mathbf{b}, \mathbf{d}$ and $\left(S_{\mathrm{a}}\right)-\mathbf{2 a}$ can be treated as a new class of atropisomeric bifunctional organocatalysts. The more flexible $\left(S_{\mathrm{a}}\right)$-2a efficiently catalysed both investigated reactions, the products being formed in $95-97 \%$ yields. Reactions were slower with the more rigid $\left(R_{\mathrm{a}}\right) \mathbf{- 1} \mathbf{b}$ and $\left(R_{\mathrm{a}}\right)-\mathbf{1 d}$ catalysts, but they gave higher asymmetric inductions. 


\section{Experimental Section}

General. All commercial starting materials were purchased from Sigma-Aldrich Kft. Hungary and Merck Kft. Hungary and were used without further purification. The organometallic reactions and the reductions were carried out in Schlenk flasks under dry nitrogen atmosphere. Solvent were typically freshly distilled or dried over molecular sieves. All reactions were monitored by thin-layer chromatography. TLC was carried out on Kieselgel $60 \mathrm{~F}_{254}$ (Merck) aluminium sheets (visualization of the products was effected by exposing the plate to UV radiation or by staining it with an aqueous solution of $\left(\mathrm{NH}_{4}\right)_{6} \mathrm{Mo}_{7} \mathrm{O}_{24}, \mathrm{Ce}\left(\mathrm{SO}_{4}\right)_{2}$ and sulfuric acid). Flash column chromatography was performed using a CombiFlash ${ }^{\circledR}$ (Teledyne ISCO). Routine ${ }^{1} \mathrm{H},{ }^{13} \mathrm{C}$ and ${ }^{19} \mathrm{~F}$ NMR spectra were obtained on a Bruker AV 300 or DRX 500 spectrometer. The chemical shifts $(\delta)$ are reported in parts per million (ppm) and the coupling constants $(J)$ in $\mathrm{Hz}$. Usually deuterated chloroform $\left(\mathrm{CDCl}_{3}\right)$ was used as the solvent, with chemical shifts measured relative to the signal for TMS $\left(\delta_{\mathrm{TMS}}=0 \mathrm{ppm}\right.$ for $\left.{ }^{1} \mathrm{H} \mathrm{NMR}\right)$ and for $\mathrm{CDCl}_{3}\left(\delta_{\mathrm{CDCl}_{3}}=77.0 \mathrm{ppm}\right.$ for $\left.{ }^{13} \mathrm{C} \mathrm{NMR}\right)$. Infrared (IR) spectra were recorded on a Perkin Elmer 1600 appliance with a Fourier Transformer. Data are given in $\mathrm{cm}^{-1}$. Melting points were determined in capillary tubes, using a Gallenkamp melting point apparatus. The enantiomeric ratios of the optically active samples were determined by high-performance liquid chromatography (HPLC) measurement and by gas chromatography (GC) analysis. HPLC was performed on a Perkin Elmer Series 200 system using a Phenomonex Lux Cellolose-1 or Amylose- 2 columns $(\mathrm{d} 5 \mu \mathrm{m}, 250 \times 4.6 \mathrm{~mm}$ ). Specific rotation of the optically active samples were determined on a Perkin Elmer $245 \mathrm{MC}$ polarimeter using sodium lamp (589 nm). Highresolution mass spectra (HRMS) were recorded on Waters LCT Premier XE spectrometer in electrospray ionization (ESI, $2.5 \mathrm{kV})$ mode, using water $(0.035 \%$ trifluoroacetic acid)/acetonitrile ( $0.035 \%$ trifluoroacetic acid) as eluent in gradient elution (5\%-95\% acetonitrile); samples were made up in acetonitrile.

Preparation and resolution ${ }^{31}$ of dicarboxylic acid $\left(R_{a}, S_{a}\right)-\mathbf{3}$ followed by selective monoesterification $^{32}$ of $\left(S_{a}\right)-3$ and multistep transformation of $\left(S_{a}\right)-4$ into the optically active aniline derivatives $\left(\left(S_{a}\right)\right.$-8a-f) were carried out analogously to the processes developed by our laboratory. ${ }^{33}$

\section{Single crystal X-ray measurements}

\section{$\left(S_{a}\right)$-2-(2-(Diethylcarbamoyl)-1H-pyrrol-1-yl)-3-(trifluoromethyl)benzoic acid $\left(\left(S_{a}\right)\right.$-6b)}

Compound $\mathbf{6 b}$ was prepared for single crystal X-ray measurements by hydrolysis of $\mathbf{5 b}^{33}$ as follows: amido ester $\left(S_{a}\right)-\mathbf{5 b}(7.00 \mathrm{mmol}, 2.58 \mathrm{~g})$ was dissolved in methanol $(25 \mathrm{~mL})$. Sodium hydroxide $(21.0 \mathrm{mmol}, 0.84 \mathrm{~g})$ was added and the mixture was stirred at room temperature for one day. The reaction was monitored by TLC (in hexane/ethyl acetate $=1 / 1\left(\mathrm{R}_{\mathrm{f}, 6 \mathrm{~b}}=0.4\right)$ ). The solvent was evaporated in vacuo. Then water $(20 \mathrm{~mL})$ and diethyl ether $(15 \mathrm{~mL})$ were added. The phases were separated, the aqueous phase was washed with diethyl ether $(2 \times 10 \mathrm{~mL})$. A solution 
of hydrogen chloride $(5 \mathrm{M}, 10 \mathrm{~mL})$ was added, the precipitate was filtered off and washed with water $(20 \mathrm{~mL})$.

$\left(\boldsymbol{S}_{\boldsymbol{a}}\right)$-6b. White solid, yield 91\%, $2.26 \mathrm{~g}, \mathrm{mp}: 105-106{ }^{\circ} \mathrm{C},[\alpha]_{\mathrm{D}}^{25}-173.5$ (c $\left.0.82 ; \mathrm{CHCl}_{3}\right)$; IR $\left(\mathrm{KBr}, v_{\max }, \mathrm{cm}^{-1}\right): 1737($ acid $\mathrm{C}=\mathrm{O}), 1562$ (amide $\left.\mathrm{C}=\mathrm{O}\right) .{ }^{1} \mathrm{H}$ NMR $\left(300 \mathrm{MHz}, \mathrm{CDCl}_{3}\right) \delta_{H} 14.35$ (s, $1 \mathrm{H}, \mathrm{COOH}), 7.91\left(\mathrm{~d}, J_{\mathrm{HH}} 7.9 \mathrm{~Hz}, 1 \mathrm{H}\right.$, phenyl), $7.80\left(\mathrm{~d}, J_{\mathrm{HH}} 7.6 \mathrm{~Hz}, 1 \mathrm{H}\right.$, phenyl), 7.65 (t, $J_{\mathrm{HH}}$ $7.8 \mathrm{~Hz}, 1 \mathrm{H}$, phenyl), 6.79 (s, $1 \mathrm{H}, \alpha-\mathrm{H}$ pyrrole), 6.62 (dd, $J_{\mathrm{HH}} 3.8,1.4 \mathrm{~Hz}, 1 \mathrm{H}, \beta^{\prime}-\mathrm{H}$ pyrrole), 6.34 $\left(\mathrm{t}, J_{\mathrm{HH}} 6.0 \mathrm{~Hz}, 1 \mathrm{H}, \beta-\mathrm{H}\right.$ pyrrole), 4.07-3.93 (m, $\left.1 \mathrm{H}, \mathrm{NCH}_{2} \mathrm{CH}_{3}\right), 3.64-3.50\left(\mathrm{~m}, 1 \mathrm{H}, \mathrm{NCH}_{2} \mathrm{CH}_{3}\right)$, 3.49-3.34 (m, $\left.1 \mathrm{H}, \mathrm{NCH}_{2} \mathrm{CH}_{3}\right), 3.33-3.20\left(\mathrm{~m}, 1 \mathrm{H}, \mathrm{NCH}_{2} \mathrm{CH}_{3}\right), 1.35\left(\mathrm{t}, J_{\mathrm{HH}} 7.1 \mathrm{~Hz}, 3 \mathrm{H}\right.$, $\left.\mathrm{NCH}_{2} \mathrm{CH}_{3}\right), 1.07\left(\mathrm{t}, J_{\mathrm{HH}} 7.1 \mathrm{~Hz}, 3 \mathrm{H}, \mathrm{NCH}_{2} \mathrm{CH}_{3}\right) .{ }^{13} \mathrm{C} \mathrm{NMR}\left(75 \mathrm{MHz}, \mathrm{CDCl}_{3}\right) \delta_{H} 167.6(\mathrm{COOH})$, $164.6\left(\mathrm{CON}\left(\mathrm{C}_{2} \mathrm{H}_{5}\right)_{2}, 137.6\right.$ (phenyl C-N), 134.6 (phenyl), 132.8 (pyrrole $\alpha-\mathrm{C}$ ), 129.8 (phenyl), 129.4 (phenyl), 128.2 (q, $J_{\mathrm{CF}} 5.0 \mathrm{~Hz}$, phenyl), 128.0 (q, $J_{\mathrm{CF}} 30.5 \mathrm{~Hz}$, phenyl), 127.1 (pyrrole $\alpha^{\prime}-$ C), 122.7 (q, $J_{\mathrm{CF}} 273.9 \mathrm{~Hz}, \mathrm{CF}_{3}$ ), 113.4 (pyrrole $\beta-\mathrm{C}$ ), 109.6 (pyrrole $\beta^{\prime}-\mathrm{C}$ ), $43.3\left(\mathrm{NCH}_{2} \mathrm{CH}_{3}\right.$ ), $39.8\left(\mathrm{NCH}_{2} \mathrm{CH}_{3}\right), 14.0\left(\mathrm{NCH}_{2} \mathrm{CH}_{3}\right), 12.0\left(\mathrm{NCH}_{2} \mathrm{CH}_{3}\right) .{ }^{19} \mathrm{~F} \mathrm{NMR}\left(282 \mathrm{MHz}, \mathrm{CDCl}_{3}\right) \delta_{F}-60.99$ (s). HRMS (ESI) $m / z$ calcd for $\mathrm{C}_{17} \mathrm{H}_{18} \mathrm{~F}_{3} \mathrm{~N}_{2} \mathrm{O}_{3}\left[(\mathrm{M}+\mathrm{H})^{+}\right]: 355.1270$, found 355.1270 .

A single crystal was grown from ethanol. The crystal was measured by Single-crystal X-ray Diffraction. A crystal of $\mathbf{6 b}$ was mounted on a loop. Intensity data were collected on a Rigaku Raxis-Rapid diffractometer (monochromator; $\mathrm{Cu}-K_{\alpha}$ radiation, $\lambda=1.54187 \AA$ ) at $93(2) \mathrm{K}$ in the range $6.858 \leq \theta \leq 71.854^{39}$. A total of 21065 reflections were collected of which 3365 were unique $[R($ int $)=0.0263, R(\sigma)=0.0162]$; intensities of 3253 reflections were greater than $2 \sigma(I)$. Completeness to $\theta=0.983$.

Crystal data: $\mathrm{C}_{17} \mathrm{H}_{17} \mathrm{~F}_{3} \mathrm{~N}_{2} \mathrm{O}_{3}$, Fwt: 354.32 , colourless platelet, size: $0.5 \times 0.5 \times 0.4 \mathrm{~mm}$, orthorhombic, space group $P 2{ }_{1} 2_{1}{ }_{1}, a=7.8704(1) \AA, b=14.1429(3) \AA, c=15.8278(3) \AA, \alpha=90^{\circ}$, $\beta=90^{\circ}, \gamma=90^{\circ}, V=1761.80(5) \AA^{3}, T=93(2) \mathrm{K}, Z=4, Z^{\prime}=1, F(000)=736, D_{x}=1.336 \mathrm{Mg} / \mathrm{m}^{3}, \mu$ $0.974 \mathrm{~mm}^{-1}$. Cell parameters were determined by least-squares using $20299\left(6.86 \leq \theta \leq 71.86^{\circ}\right)$ reflections. ${ }^{40}$

A numerical absorption correction ${ }^{41}$ was applied to the data (the minimum and maximum transmission factors were 0.628 and 0.759 ). The structure was solved by direct methods ${ }^{42}$ (and subsequent difference syntheses). Anisotropic full-matrix least-squares refinement ${ }^{42}$ on $F^{2}$ for all non-hydrogen atoms yielded $R_{1}=0.0327$ and $w R^{2}=0.0821$ for $1332[I>2 \sigma(I)]$ and $R_{1}=0.0343$ and $w R^{2}=0.0836$ for all (3365) intensity data, (number of parameters $=232$, goodness-of-fit $=$ 1.096 , the maximum and mean shift/esd is 0.000 and 0.000 ). The absolute structure parameters are: Flack (x) 0.08(3), Hooft (y) 0.08(3), Parsons (z) ${ }^{43}$ 0.08(3) (Friedel coverage: 0.725, Friedel fraction max.: 0.967, Friedel fraction full: 0.993). The maximum and minimum residual electron density in the final difference map was 0.51 and $-0.24 \mathrm{e} . \AA^{-3}$. The weighting scheme applied was $w=1 /\left[\sigma^{2}\left(F_{o}^{2}\right)+(0.03500 \times 6548 P)^{2}+0.6548 P\right]$ where $P=\left(F_{o}^{2}+2 F_{c}^{2}\right) / 3$. Hydrogen atomic positions were calculated from assumed geometries except $\mathrm{H}_{3} \mathrm{O}$ that was located in difference maps. Hydrogen atoms were included in structure factor calculations but they were not refined. The isotropic displacement parameters of the hydrogen atoms were approximated from the $U(\mathrm{eq})$ value of the atom they were bonded to. ORTEP style molecular structure diagram can be found in Figure 1. 
Crystallographic data (including structure factors) for structure $\mathbf{6 b}$ have been deposited with the Cambridge Crystallographic Data Centre as supplementary publication no. CCDC 1434065. Copies of the data can be obtained free of charge on application to CCDC, 12 Union Road, Cambridge CB2 1EZ, UK, (fax: ţ44-(0)1223 336033 or e-mail: deposit@ccdc.cam.ac.uk).

Synthesis of thioureas $\left(\boldsymbol{R}_{\boldsymbol{a}}\right)$-1a-f, general procedure. A sample among compounds $\left(S_{a}\right)$-8a-f $(0.5 \mathrm{mmol})$ was dissolved in dry dichloromethane $(2 \mathrm{~mL})$ and phenyl isothiocyanate $(0.5 \mathrm{mmol}$, $59.6 \mu \mathrm{L})$ or 3,5 -bis(trifluoromethyl)phenyl isothiocyanate $(0.5 \mathrm{mmol}, 91.3 \mu \mathrm{L})$ was added. The reaction mixture was stirred for $30 \mathrm{~min}$. The organic solvent was evaporated in vacuo and the residue was purified by flash chromatography. Enantiomeric purities of 1a-f products were checked by HPLC and each samples were pure enantiomers (ee $>99 \%$ ).

\section{$\left(\boldsymbol{R}_{\mathrm{a}}\right)$-1-[3,5-Bis(trifluoromethyl)phenyl]-3-[2-(2-dimethylaminomethyl)-1H-pyrrol-1-yl-3-}

(trifluoromethyl)phenyl]thiourea $\left(\left(\boldsymbol{R}_{\mathbf{a}}\right)-1 a\right)$. Yellow oil, yield $89 \%, 0.25 \mathrm{~g},[\alpha]_{\mathrm{D}}^{25}-77.8(c 0.47$; $\left.\mathrm{CHCl}_{3}\right)$; IR ( $\left.\mathrm{KBr}, v_{\max }, \mathrm{cm}^{-1}\right): 1279(\mathrm{C}=\mathrm{S}) .{ }^{1} \mathrm{H} \mathrm{NMR}\left(300 \mathrm{MHz}, \mathrm{CDCl}_{3}\right) \delta_{\mathrm{H}} 7.88-7.74(\mathrm{~m}, 3 \mathrm{H}$, phenyl), $7.74-7.55$ (m, 3H, phenyl), $6.74\left(\mathrm{~s}, 1 \mathrm{H}, \alpha-\mathrm{H}\right.$ pyrrole), $6.30-6.17\left(\mathrm{~m}, 2 \mathrm{H}, \beta+\beta^{\prime}-\mathrm{H}\right.$ pyrrole), 3.26 (d, $\left.J_{\mathrm{HH}} 13.9 \mathrm{~Hz}, 1 \mathrm{H}, \mathrm{CH}_{2}\right), 3.16\left(\mathrm{~d}, J_{\mathrm{HH}} 13.9 \mathrm{~Hz}, 1 \mathrm{H}, \mathrm{CH}_{2}\right), 2.15\left(\mathrm{~s}, 6 \mathrm{H}, \mathrm{N}\left(\mathrm{CH}_{3}\right)_{2}\right)$. ${ }^{13} \mathrm{C}$ NMR $\left(75 \mathrm{MHz}, \mathrm{CDCl}_{3}\right) \delta_{\mathrm{C}} 179.1(\mathrm{C}=\mathrm{S}), 141.8$ (phenyl C-N thiourea), 140.3 (phenyl C-N thiourea), 132.6 (phenyl C-N pyrrole), 132.3 (q, $J_{\mathrm{CF}} 33.6 \mathrm{~Hz}, 2 \mathrm{C}$, phenyl), 131.6, 130.0 (q, $J_{\mathrm{CF}}$ $30.6 \mathrm{~Hz}$, phenyl), 129.6 (phenyl), 128.4 (phenyl), 125.8 (phenyl), 124.4 (q, $J_{\mathrm{CF}} 5.2 \mathrm{~Hz}$, phenyl), 122.9 (q, $J_{\mathrm{CF}} 271.2 \mathrm{~Hz}, 2 \mathrm{C}, \mathrm{CF}_{3}$ ), 122.7 (q, $J_{\mathrm{CF}} 274.2 \mathrm{~Hz}, \mathrm{CF}_{3}$ ), 122.7 (phenyl), 122.6 (pyrrole $\alpha^{\prime}-$ C), 118.1 (sep, $J_{\mathrm{CF}}=3.9 \mathrm{~Hz}$, phenyl), 111.6 (pyrrole $\alpha-\mathrm{C}$ ), 108.4 (2C, pyrrole $\beta+\beta^{\prime}-\mathrm{C}$ ), 54.4 $\left(\mathrm{CH}_{2}\right), 43.6\left(2 \mathrm{C}, \mathrm{CH}_{3}\right) .{ }^{19} \mathrm{~F}$ NMR $\left(282 \mathrm{MHz}, \mathrm{CDCl}_{3}\right) \delta-60.76(\mathrm{~s}, 3 \mathrm{~F}),-62.89$ (s, 6F). HRMS (ESI) $m / z$ calcd for $\mathrm{C}_{23} \mathrm{H}_{20} \mathrm{~F}_{9} \mathrm{~N}_{4} \mathrm{~S}\left[(\mathrm{M}+\mathrm{H})^{+}\right]$: 555.1265, found 555.1278.

\section{$\left(\boldsymbol{R}_{\mathrm{a}}\right)$-1-[3,5-Bis(trifluoromethyl)phenyl]-3-[2-(2-diethylaminomethyl)-1H-pyrrol-1-yl-3-}

(trifluoromethyl)phenyl]thiourea $\left(\left(\boldsymbol{R}_{\mathrm{a}}\right)-1 \mathrm{~b}\right)$. Yellow solid, yield $66 \%, 0,19 \mathrm{~g}, \mathrm{mp}: 74-75^{\circ} \mathrm{C}$, $[\alpha]_{\mathrm{D}}^{25}-98.2\left(c\right.$ 0.47; $\left.\mathrm{CHCl}_{3}\right)$; IR $\left(\mathrm{KBr}, v_{\max }, \mathrm{cm}^{-1}\right): 1279(\mathrm{C}=\mathrm{S}) .{ }^{1} \mathrm{H} \mathrm{NMR}\left(500 \mathrm{MHz}, \mathrm{CDCl}_{3}\right) \delta_{H}$ 7.87 (s, 2H, phenyl), $7.75-7.68(\mathrm{~m}, 1 \mathrm{H}$, phenyl), $7.63-7.54(\mathrm{~m}, 2 \mathrm{H}$, phenyl), $7.51(\mathrm{~s}, 1 \mathrm{H}$, phenyl), 6,79 (s, 1H, $\alpha-\mathrm{H}$ pyrrole), 6,28 (s, 1H, $\beta^{\prime}-\mathrm{H}$ pyrrole), 6.25 (t, $J_{\mathrm{HH}} 3.0 \mathrm{~Hz}, 1 \mathrm{H}, \beta-\mathrm{H}$ pyrrole), 3.52 (d, J $\left.J_{\mathrm{HH}} 14.3 \mathrm{~Hz}, 1 \mathrm{H}, \mathrm{CH}_{2}\right), 3.44$ (d, $\left.J_{\mathrm{HH}} 14.3 \mathrm{~Hz}, 1 \mathrm{H}, \mathrm{CH}_{2}\right), 2.85-2.73(\mathrm{~m}, 2 \mathrm{H}$, $\left.\mathrm{N}\left(\mathrm{CH}_{2} \mathrm{CH}_{3}\right)_{2}\right), 2.72-2.59\left(\mathrm{~m}, 2 \mathrm{H}, \mathrm{N}\left(\mathrm{CH}_{2} \mathrm{CH}_{3}\right)_{2}\right), 1.01\left(\mathrm{t}, J_{\mathrm{HH}} 7.1 \mathrm{~Hz}, 6 \mathrm{H}, \mathrm{N}\left(\mathrm{CH}_{2} \mathrm{CH}_{3}\right)_{2}\right) .{ }^{13} \mathrm{C}$ NMR $\left(75 \mathrm{MHz}, \mathrm{CDCl}_{3}\right) \delta_{C} 175.4(\mathrm{C}=\mathrm{S}), 144.9$ (phenyl C-N thiourea), 140.72 (phenyl C-N thiourea), 131.9 (q, $J_{\mathrm{CF}} 33.5 \mathrm{~Hz}, 2 \mathrm{C}$, phenyl), 131.6 (phenyl C-N pyrrole), 131.5 (phenyl), 131.3 (phenyl), 129.5 (phenyl), 129.3 (q, $J_{\mathrm{CF}} 30.3 \mathrm{~Hz}$, phenyl), 125.9 (phenyl), 123.1 (q, $J_{\mathrm{CF}} 272.9 \mathrm{~Hz}$, 2C, $\mathrm{CF}_{3}$ ), 123.0 (d, $J_{\mathrm{CF}} 5.2 \mathrm{~Hz}$, phenyl), 122.9 (q, $J_{\mathrm{CF}} 273.7 \mathrm{~Hz}, \mathrm{CF}_{3}$ ), 121.8 (pyrrole $\alpha-\mathrm{C}$ ), 121.7 (pyrrole $\alpha^{\prime}-\mathrm{C}$ ), 117.0 (sep, $J_{\mathrm{CF}} 3.6 \mathrm{~Hz}$, phenyl)), 112.4 (pyrrole $\beta-\mathrm{C}$ ), 108.6 (pyrrole $\beta^{\prime}-\mathrm{C}$ ), 46.4 $\left(\mathrm{CH}_{2}\right), 45.4\left(2 \mathrm{C}, \mathrm{CH}_{2} \mathrm{CH}_{3}\right), 8.8\left(2 \mathrm{C}, \mathrm{CH}_{2} \mathrm{CH}_{3}\right) .{ }^{19} \mathrm{~F} \mathrm{NMR}\left(282 \mathrm{MHz}, \mathrm{CDCl}_{3}\right) \delta_{F}-60.67(\mathrm{~s}, 3 \mathrm{~F})$, $-62.85(\mathrm{~s}, 6 \mathrm{~F})$. HRMS (ESI) $m / z$ calcd for $\mathrm{C}_{25} \mathrm{H}_{24} \mathrm{~F}_{9} \mathrm{~N}_{4} \mathrm{~S}\left[(\mathrm{M}+\mathrm{H})^{+}\right]: 583.1578$ found 583,1591.

$\left(\boldsymbol{R}_{\mathrm{a}}\right)$-1-[3,5-Bis(trifluoromethyl)phenyl]-3-[2-(2-dibutylaminomethyl)-1H-pyrrol-1-yl-3(trifluoromethyl)phenyl]thiourea $\left(\left(\boldsymbol{R}_{\mathrm{a}}\right)-1 \mathrm{c}\right)$. Yellow oil, yield $62 \%, 0,19 \mathrm{~g},[\alpha]_{\mathrm{D}}^{25}-110.0(c$ 0.15; $\left.\mathrm{CHCl}_{3}\right)$; IR $\left(\mathrm{KBr}, v_{\max }, \mathrm{cm}^{-1}\right): 1279(\mathrm{C}=\mathrm{S}) .{ }^{1} \mathrm{H}$ NMR $\left(500 \mathrm{MHz}, \mathrm{CDCl}_{3}\right) \delta_{H} 7.87(\mathrm{~s}, 2 \mathrm{H}$, 
phenyl), $7.76-7.71(\mathrm{~m}, 1 \mathrm{H}$, phenyl), $7.63-7.56(\mathrm{~m}, 2 \mathrm{H}$, phenyl), 7.52 (s, 1H, phenyl), 6.78 (s, $1 \mathrm{H}, \alpha-\mathrm{H}$ pyrrole), $6.30-6.19\left(\mathrm{~m}, 2 \mathrm{H}, \beta+\beta^{\prime}-\mathrm{H}\right.$ pyrrole), $3.52\left(\mathrm{~d}, J_{\mathrm{HH}} 14.3 \mathrm{~Hz}, 1 \mathrm{H}, \mathrm{CH}_{2}\right), 3.43(\mathrm{~d}$, $\left.J_{\mathrm{HH}} 14.3 \mathrm{~Hz}, 1 \mathrm{H}, \mathrm{CH}_{2}\right), 2.73-2.63\left(\mathrm{~m}, 2 \mathrm{H},\left(\mathrm{CH}_{2}\right)_{3} \mathrm{CH}_{3}\right), 2.58-2.48\left(\mathrm{~m}, 2 \mathrm{H},\left(\mathrm{CH}_{2}\right)_{3} \mathrm{CH}_{3}\right), 1.42-$ $1.31\left(\mathrm{~m}, 4 \mathrm{H},\left(\mathrm{CH}_{2}\right)_{3} \mathrm{CH}_{3}\right), 1.29-1.17\left(\mathrm{~m}, 4 \mathrm{H},\left(\mathrm{CH}_{2}\right)_{3} \mathrm{CH}_{3}\right), 0.86\left(\mathrm{t}, J_{\mathrm{HH}} 7.3 \mathrm{~Hz}, 6 \mathrm{H},\left(\mathrm{CH}_{2}\right)_{3} \mathrm{CH}_{3}\right)$. ${ }^{13} \mathrm{C}$ NMR $\left(75 \mathrm{MHz}, \mathrm{CDCl}_{3}\right) \delta_{C} 179.8(\mathrm{C}=\mathrm{S}), 140.7$ (phenyl C-N thiourea), 140.0 (phenyl C-N thiourea), 133.4 (q, $J_{\mathrm{CF}} 34.3 \mathrm{~Hz}$, phenyl C-N pyrrole), 131.9 (q, $J_{\mathrm{CF}} 33.3 \mathrm{~Hz}, 2 \mathrm{C}$, phenyl), 131.1 (phenyl), 129.5 (phenyl), 126.2 (phenyl), 125.8 (phenyl), 125,7 (phenyl), 123.1 (q, $J_{\mathrm{CF}} 272.9 \mathrm{~Hz}$, 2C, $\mathrm{CF}_{3}$ ), 122.8 (q, $J_{\mathrm{CF}} 273.8 \mathrm{~Hz}, \mathrm{CF}_{3}$ ), 121.5 (phenyl), 121.4 (pyrrole $\alpha-\mathrm{C}$ ), 120.5 (q, $J_{\mathrm{CF}} 3.8 \mathrm{~Hz}$, phenyl), 117.0 (m, pyrrole $\alpha^{\prime}-\mathrm{C}$ ), 112.6 (pyrrole $\beta-\mathrm{C}$ ), 108.7 (pyrrole $\beta^{\prime}-\mathrm{C}$ ), 52.0 (2C, $\left.\left(\mathrm{CH}_{2}\right)_{3} \mathrm{CH}_{3}\right), 47.8\left(\mathrm{CH}_{2}\right), 25.8\left(2 \mathrm{C},\left(\mathrm{CH}_{2}\right)_{3} \mathrm{CH}_{3}\right), 20.3\left(2 \mathrm{C},\left(\mathrm{CH}_{2}\right)_{3} \mathrm{CH}_{3}\right), 13.7\left(2 \mathrm{C},\left(\mathrm{CH}_{2}\right)_{3} \mathrm{CH}_{3}\right)$. ${ }^{19} \mathrm{~F}$ NMR $\left(282 \mathrm{MHz}, \mathrm{CDCl}_{3}\right) \delta_{F}-60.66(\mathrm{~s}, 3 \mathrm{~F}),-62.87(\mathrm{~s}, 6 \mathrm{~F})$. HRMS (ESI) $\mathrm{m} / z$ calcd for $\mathrm{C}_{29} \mathrm{H}_{32} \mathrm{~F}_{9} \mathrm{~N}_{4} \mathrm{~S}\left[(\mathrm{M}+\mathrm{H})^{+}\right]: 639.2204$, found 639.2207.

$\left(\boldsymbol{R}_{\mathrm{a}}\right)$-1-[3,5-Bis(trifluoromethyl)phenyl]-3-[2-(2-pyrrolidin-1-ylmethyl)-1H-pyrrol-1-yl-3(trifluoromethyl)phenyl]thiourea $\left(\left(\boldsymbol{S}_{\mathbf{a}}\right)-1 \mathrm{~d}\right)$. Yellow solid, yield $60 \%, 0.17 \mathrm{~g}, \mathrm{mp}: 88-89{ }^{\circ} \mathrm{C}$, $[\alpha]_{\mathrm{D}}^{25}-56.8\left(c 0.13 ; \mathrm{CHCl}_{3}\right)$; IR $\left(\mathrm{KBr}, v_{\max }, \mathrm{cm}^{-1}\right)$ : $1279(\mathrm{C}=\mathrm{S}) .{ }^{1} \mathrm{H} \mathrm{NMR}\left(500 \mathrm{MHz}, \mathrm{CDCl}_{3}\right) \delta_{H}$ 7.89 (s, 2H, phenyl), $7.68-7.49$ (m, 3H, phenyl), 7.46 (s, 1H, phenyl), 6.81 (s, 1H, $\alpha-\mathrm{H}$ pyrrole), $6.36-6.19\left(\mathrm{~m}, 2 \mathrm{H}, \beta+\beta^{\prime}-\mathrm{H}\right.$ pyrrole), $3,78\left(\mathrm{~d}, J_{\mathrm{HH}} 13.9 \mathrm{~Hz}, 1 \mathrm{H}, \mathrm{CH}_{2}\right), 3.56\left(\mathrm{~d}, J_{\mathrm{HH}} 13.9 \mathrm{~Hz}, 1 \mathrm{H}\right.$, $\left.\mathrm{CH}_{2}\right), 2.92\left(\mathrm{~s}, 4 \mathrm{H}\right.$, pyrrolidine $\left.\mathrm{CH}_{2}\right), 2.00\left(\mathrm{~s}, 4 \mathrm{H}\right.$, pyrrolidine $\left.\mathrm{CH}_{2}\right) .{ }^{13} \mathrm{C} \mathrm{NMR}\left(75 \mathrm{MHz}, \mathrm{CDCl}_{3}\right)$ $\delta_{C} 171.9(\mathrm{C}=\mathrm{S}), 147.6$ (phenyl C-N thiourea), 141.1 (phenyl C-N thiourea), 131.7 (q, $J_{\mathrm{CF}} 33.3$ Hz, 2C, phenyl), 130.7 (phenyl), 129.9 (phenyl), 129.6 (phenyl), 129.0 (q, $J_{\mathrm{CF}} 29.9 \mathrm{~Hz}$, phenyl), 126.1 (phenyl), 125.8 (phenyl), 123.2 (q, $J_{\mathrm{CF}} 272.8 \mathrm{~Hz}, 2 \mathrm{C}, \mathrm{CF}_{3}$ ), 123.0 (q, $J_{\mathrm{CF}} 273.6 \mathrm{~Hz}, \mathrm{CF}_{3}$ ), 122.0 (q, $J_{\mathrm{CF}} 5.1 \mathrm{~Hz}$, phenyl), 120.8 (2C, pyrrole $\left.\alpha+\alpha^{\prime}-\mathrm{C}\right), 116.2$ (sep, $J_{\mathrm{CF}} 3.7 \mathrm{~Hz}$, phenyl), 112.2 (pyrrole $\beta$-C), 108.7 (pyrrole $\left.\beta^{\prime}-\mathrm{C}\right), 53.3\left(2 \mathrm{C}\right.$, pyrrolidine), $50.6\left(\mathrm{CH}_{2}\right), 23.4\left(2 \mathrm{C}\right.$, pyrrolidine) ${ }^{19} \mathrm{~F}$ NMR (282 MHz, $\left.\mathrm{CDCl}_{3}\right) \delta_{F}-60.68(\mathrm{~s}, 3 \mathrm{~F}),-62.79(\mathrm{~s}, 6 \mathrm{~F})$. HRMS (ESI) $\mathrm{m} / \mathrm{z}$ calcd for $\mathrm{C}_{25} \mathrm{H}_{22} \mathrm{~F}_{9} \mathrm{~N}_{4} \mathrm{~S}\left[(\mathrm{M}+\mathrm{H})^{+}\right]: 581.1421$, found 581.1396 .

\section{1-[3,5-Bis(trifluoromethyl)phenyl]-3-[( $\left.R_{\mathrm{a}}\right)-2-[2-[$ methyl-((S)-1-phenylethyl)aminomethyl]-}

1H-pyrrol-1-yl]-3-(trifluoromethyl)phenyl]thiourea $\left(\left(\boldsymbol{R}_{\mathrm{a}}\right)-1 \mathrm{e}\right)$. Yellow solid, yield $62 \%$, $0.19 \mathrm{~g}, \mathrm{mp}: 80-81^{\circ} \mathrm{C},[\alpha]_{\mathrm{D}}^{25}-121.3\left(c 0.11 ; \mathrm{CHCl}_{3}\right)$; IR $\left(\mathrm{KBr}, v_{\max }, \mathrm{cm}^{-1}\right): 1279(\mathrm{C}=\mathrm{S}) .{ }^{1} \mathrm{H}$ NMR $\left(300 \mathrm{MHz}, \mathrm{CDCl}_{3}\right) \delta_{H} 8.02-7.84(\mathrm{~m}, 2 \mathrm{H}$, phenyl), $7.80-7.53(\mathrm{~m}, 6 \mathrm{H}$, phenyl), $7.35-7.17(\mathrm{~m}$, $3 \mathrm{H}$, phenyl), 6.67 (s, 1H, $\alpha-\mathrm{H}$ pyrrole), $6.27-6.17$ (m, 2H, $\beta+\beta^{\prime}-\mathrm{H}$ pyrrole), 3,57 (q, 1H, $J_{\mathrm{HH}} 6.8$ $\mathrm{Hz}, 1 \mathrm{H}, \mathrm{CH}$ chiral) 3.53 (d, $\left.J_{\mathrm{HH}} 13.8 \mathrm{~Hz}, 1 \mathrm{H}, \mathrm{CH}_{2}\right), 3.11$ (d, $\left.J_{\mathrm{HH}} 13.8 \mathrm{~Hz}, 1 \mathrm{H}, \mathrm{CH}_{2}\right), 2.15$ (s, 3H, $\left.\mathrm{CH}_{3}\right), 1.22\left(\mathrm{~d}, J_{\mathrm{HH}} 6.8 \mathrm{~Hz}, 3 \mathrm{H}, \mathrm{CH}_{3}\right) .{ }^{13} \mathrm{C} \mathrm{NMR}\left(75 \mathrm{MHz}, \mathrm{CDCl}_{3}\right) \delta_{\mathrm{C}} 180.3(\mathrm{C}=\mathrm{S}), 141.2$ (phenyl C-C chiral), 139.7 (phenyl C-N thiourea), 139.4 (phenyl C-N thiourea), 133.4 (d, $J_{\mathrm{CF}} 1.2 \mathrm{~Hz}$, phenyl), 132.6 (phenyl), 131.9 (q, $J_{\mathrm{CF}} 33.7 \mathrm{~Hz}, 2 \mathrm{C}$, phenyl), 129.4 (phenyl), 129.2 (phenyl), 129.1 (q, $J_{\mathrm{CF}} 30,8 \mathrm{~Hz}$, phenyl), 128.8 (2C, phenyl), 128.0 (phenyl), 127.8 (2C, phenyl), 125.8 (q, $J_{\mathrm{CF}} 4.4 \mathrm{~Hz}$, phenyl), 125.2 (phenyl), 124.0 (phenyl), 123.9 (pyrrole $\alpha-\mathrm{C}$ ), 122.9 (q, $J_{\mathrm{CF}} 272.9 \mathrm{~Hz}$, 2C, $\mathrm{CF}_{3}$ ), 122.6 (q, $J_{\mathrm{CF}} 274.9 \mathrm{~Hz}, \mathrm{CF}_{3}$ ), 118.9 (sep, $J_{\mathrm{CF}} 3.8 \mathrm{~Hz}$, phenyl), 111.9 (pyrrole $\beta-\mathrm{C}$ ), 108.6 (pyrrole $\left.\beta^{\prime}-\mathrm{C}\right), 63.9$ (CH chiral), 49.7 $\left(\mathrm{CH}_{2}\right), 37.8\left(\mathrm{CH}_{3}, 16.8\left(\mathrm{CH}_{3}\right) .{ }^{19} \mathrm{~F}\right.$ NMR $(282 \mathrm{MHz}$, $\left.\mathrm{CDCl}_{3}\right) \delta_{\mathrm{F}}-60.69(\mathrm{~s}, 3 \mathrm{~F}),-62.89(\mathrm{~s}, 6 \mathrm{~F})$. HRMS (ESI) $\mathrm{m} / z$ calcd for $\mathrm{C}_{30} \mathrm{H}_{26} \mathrm{~F}_{9} \mathrm{~N}_{4} \mathrm{~S}\left[(\mathrm{M}+\mathrm{H})^{+}\right]$: 645.1734 , found 645.1718 . 
( $\left.\boldsymbol{R}_{\mathrm{a}}\right)$-1-[2-(2-Diethylaminomethyl)-1 H-pyrrol-1-yl]-3-(trifluoromethyl)phenyl]-3-phenylthiourea $\left(\left(\boldsymbol{R}_{\mathbf{a}}\right)-1 \mathbf{f}\right)$. Yellow solid, yield $71 \%, 0.16 \mathrm{~g}, \mathrm{mp}: 114-115^{\circ} \mathrm{C},[\alpha]_{\mathrm{D}}^{25}-74.7\left(c 0.40 ; \mathrm{CHCl}_{3}\right)$; IR $\left(\mathrm{KBr}, v_{\max }, \mathrm{cm}^{-1}\right): 1279(\mathrm{C}=\mathrm{S}) .{ }^{1} \mathrm{H}$ NMR $\left(300 \mathrm{MHz}, \mathrm{CDCl}_{3}\right) \delta_{H} 8.16\left(\mathrm{~d}, J_{\mathrm{HH}} 7.9 \mathrm{~Hz}, 1 \mathrm{H}\right.$, phenyl), 7.65 (d, $J_{\mathrm{HH}} 7.7 \mathrm{~Hz}, 1 \mathrm{H}$, phenyl), 7.56 (t, $J_{\mathrm{HH}} 7.9 \mathrm{~Hz}, 1 \mathrm{H}$, phenyl), 7.27 (t, $J_{\mathrm{HH}} 7.4 \mathrm{~Hz}$, 2H, phenyl), 7.16 (t, $J_{\mathrm{HH}} 7.4 \mathrm{~Hz}, 1 \mathrm{H}$, phenyl), 6.98 (d, $J_{\mathrm{HH}} 7.6 \mathrm{~Hz}, 2 \mathrm{H}$, phenyl), 6.73 (s, $1 \mathrm{H}, \alpha-\mathrm{H}$ pyrrole), 6.27 (t, $J_{\mathrm{HH}} 3.0 \mathrm{~Hz}, 1 \mathrm{H}, \beta-\mathrm{H}$ pyrrole), 6.16 (s, 1H, $\beta^{\prime}-\mathrm{H}$ pyrrole), 3.17 (d, $J_{\mathrm{HH}} 14.3 \mathrm{~Hz}$, $\left.1 \mathrm{H}, \mathrm{CH}_{2}\right), 2.96\left(\mathrm{~d}, J_{\mathrm{HH}} 14.3 \mathrm{~Hz}, 1 \mathrm{H}, \mathrm{CH}_{2}\right), 2.15-1.95\left(\mathrm{~m}, 4 \mathrm{H}, \mathrm{CH}_{2}\right), 0.58$ (t, $J_{\mathrm{HH}} 7.0 \mathrm{~Hz}, 6 \mathrm{H}$, $\left.\mathrm{CH}_{3}\right) .{ }^{13} \mathrm{C} \mathrm{NMR}\left(75 \mathrm{MHz}, \mathrm{CDCl}_{3}\right) \delta_{C} 180.9(\mathrm{C}=\mathrm{S}), 140.3$ (phenyl C-N thiourea), 137.4 (phenyl C-N thiourea), 133.4 (phenyl), 133.2 (phenyl), 131.3 (phenyl), 129.9 (2C, phenyl), 129.6 (q, $J_{\mathrm{CF}}$ $30.7 \mathrm{~Hz}$, phenyl), 128.8 (phenyl), 126.5 (phenyl), 124.8, (q, $J_{\mathrm{CF}} 5.1 \mathrm{~Hz}$, phenyl), 124.3 (pyrrole $\alpha-\mathrm{C}$ ), 124.2 (2C, phenyl), 122.9 (q, $J_{\mathrm{CF}} 271.5 \mathrm{~Hz}, \mathrm{CF}_{3}$ ), 110.6 (pyrrole $\beta-\mathrm{C}$ ), 108.6 (pyrrole $\beta^{\prime}-\mathrm{C}$ ), $47.4\left(\mathrm{CH}_{2}\right), 45.2\left(2 \mathrm{C}, \mathrm{CH}_{2}\right), 9.5\left(2 \mathrm{C}, \mathrm{CH}_{3}\right) .{ }^{19} \mathrm{~F}$ NMR $\left(282 \mathrm{MHz}, \mathrm{CDCl}_{3}\right) \delta-60.81$ (s). HRMS (ESI) $m / z$ calcd for $\mathrm{C}_{23} \mathrm{H}_{26} \mathrm{~F}_{3} \mathrm{~N}_{4} \mathrm{~S}\left[(\mathrm{M}+\mathrm{H})^{+}\right]$: 447.1830, found 447.1811 .

\section{Synthesis of $\left(S_{a}\right)-2 \mathrm{a}$ and $\left(S_{a}\right)-2 \mathrm{~b}$}

$\left(S_{\text {a }}\right)$-1-[2-[(1,3-Dioxoisoindolin-2-yl)methyl]-6-(trifluoromethyl)phenyl]- $N, N$-diethyl-1 $H$ pyrrole-2-carboxamide $\left(\left(S_{\mathrm{a}}\right)-12\right)$. Compound $\left(S_{\mathrm{a}}\right)-\mathbf{1 1}{ }^{32}(1.0 \mathrm{mmol}, 0.34 \mathrm{~g})$ was dissolved in dry dichloromethane $(4 \mathrm{~mL})$ and thionyl chloride $(1.2 \mathrm{mmol}, 0.09 \mathrm{~mL})$ was added dropwise at $0{ }^{\circ} \mathrm{C}$. The reaction mixture was stirred for $30 \mathrm{~min}$ at room temperature. The solvent was evaporated in vacuo. The residue was dissolved in dry dimethylformamide $(2 \mathrm{~mL})$ and a solution of phthalimide potassium salt $(2.2 \mathrm{mmol}, 0.41 \mathrm{~g})$ in $2 \mathrm{~mL}$ dry dimethylformamide was added. The mixture was stirred for 6 days at $50{ }^{\circ} \mathrm{C}$. Water $(30 \mathrm{~mL})$ and dichloromethane $(3 \mathrm{~mL})$ was added. The phases was separated, the aqueous phase was washed with dichloromethane $(2 \times 3 \mathrm{ml})$, then the collected organic phase was washed with water $(2 \times 30 \mathrm{ml})$, dried over sodium sulfate and concentrated under reduce pressure to get the product as a solid.

$\left(\boldsymbol{S}_{\mathrm{a}}\right)$-12. White solid, yield 98\%, $0.46 \mathrm{~g}, \mathrm{mp}: 172-173{ }^{\circ} \mathrm{C},[\alpha]_{\mathrm{D}}^{25}-291.1\left(c 1.0 ; \mathrm{CHCl}_{3}\right), e e>99 \%$; HPLC: Phenomenex Lux Cellulose-2 column, eluent $n$-hexane/ethanol $=75 / 25,0,8 \mathrm{~mL} / \mathrm{min}$, uv detector $222 \mathrm{~nm}, 20^{\circ} \mathrm{C}, \mathrm{t}_{(S)}$ : $10.8 \mathrm{~min}, \mathrm{t}_{(R)}$ : $18.9 \mathrm{~min}$; IR $\left(\mathrm{KBr}, v_{\max }, \mathrm{cm}^{-1}\right): 1726$ (imide $\mathrm{C}=\mathrm{O}$ ), 1619 (amide $\mathrm{C}=\mathrm{O}) .{ }^{1} \mathrm{H}$ NMR $\left(\mathrm{CDCl}_{3}, 300 \mathrm{MHz}\right) \delta_{H} 7.88-7.80(\mathrm{~m}, 2 \mathrm{H}$, phenyl), $7.74-7.67$ (m, 2H, phenyl), $7.60\left(\mathrm{~d}, J_{\mathrm{HH}} 7.5 \mathrm{~Hz}, 1 \mathrm{H}\right.$, phenyl), $7.51\left(\mathrm{~d}, J_{\mathrm{HH}} 7.2 \mathrm{~Hz}, 1 \mathrm{H}\right.$, phenyl), 7.42 (t, $J_{\mathrm{HH}} 7.8$ $\mathrm{Hz}, 1 \mathrm{H}$, phenyl), 6.98 (s, 1H, $\alpha-\mathrm{H}$ pyrrole), $6.61-6.52$ (m, 1H, $\beta^{\prime}-\mathrm{H}$ pyrrole), 6.33 (t, $J_{\mathrm{HH}} 3.3 \mathrm{~Hz}$, $1 \mathrm{H}, \beta-\mathrm{H}$ pyrrole), 5.02 (d, $\left.J_{\mathrm{HH}} 15.9 \mathrm{~Hz}, 1 \mathrm{H}, \mathrm{PhCH}_{2}-\mathrm{N}\right), 4.29$ (d, $\left.J_{\mathrm{HH}} 15.9 \mathrm{~Hz}, 1 \mathrm{H}, \mathrm{PhCH}_{2}-\mathrm{N}\right)$,

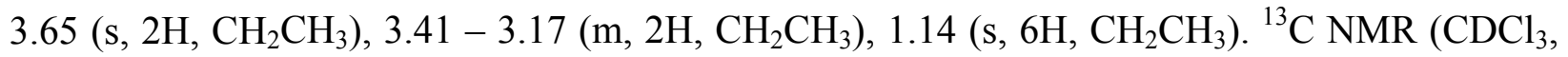
$75 \mathrm{MHz}) \delta_{C} 167.8\left(2 \mathrm{C}\right.$, isoindolinone C), 162.1 (amide C), 138.4 (phenyl C-N), 137.3 (d, $J_{\mathrm{CF}}$ $1.65 \mathrm{~Hz}$, phenyl), 134.0 (2C, phenyl), 132.0 (phenyl), 131.4 (2C, phenyl), 128.6 (phenyl), 128.4 (phenyl), 127.6 (q, $J_{\mathrm{CF}} 30.0 \mathrm{~Hz}$, phenyl), 127.2 (phenyl), 125.4 (q, $J_{\mathrm{CF}} 5.2 \mathrm{~Hz}$, phenyl), 123.3 (2C, $\alpha+\alpha^{\prime}-\mathrm{H}$ pyrrole), 123.2 (q, $\left.J_{\mathrm{CF}} 263.1 \mathrm{~Hz}, \mathrm{CF}_{3}\right), 111.4$ ( $\beta$-H pyrrole), 108.0 ( $\beta^{\prime}$-H pyrrole), $40.9\left(2 \mathrm{C}, \mathrm{CH}_{2} \mathrm{CH}_{3}\right), 37.5\left(\mathrm{CH}_{2}\right), 13.3\left(2 \mathrm{C}, \mathrm{CH}_{2} \mathrm{CH}_{3}\right) .{ }^{19} \mathrm{~F} \mathrm{NMR}\left(\mathrm{CDCl}_{3}, 282 \mathrm{MHz}\right) \delta_{F}-60.5(\mathrm{~s})$. HRMS (ESI) $m / z$ calcd for $\mathrm{C}_{25} \mathrm{H}_{23} \mathrm{~F}_{3} \mathrm{~N}_{3} \mathrm{O}_{3}\left[(\mathrm{M}+\mathrm{H})^{+}\right]: 470.1692$, found 470.1701 .

$\left(S_{\mathrm{a}}\right)$-1-[2-(Aminomethyl)-6-(trifluoromethyl)phenyl]- $\boldsymbol{N}, \boldsymbol{N}$-diethyl-1H-pyrrole-2-carboxamide hydrochloride $\left(\left(\boldsymbol{S}_{\mathrm{a}}\right)-\mathbf{1 3 . H C l}\right)$. Compound $\left(S_{\mathrm{a}}\right)-\mathbf{1 2}(0.8 \mathrm{mmol}, 0.38 \mathrm{~g})$ was dissolved in 
ethanol $(4 \mathrm{ml})$ and hydrazine hydrate $(0.96 \mathrm{mmol}, 76 \mu \mathrm{L})$ was added. The formation of the product was monitored by TLC (hexane/ethyl acetate $=1 / 1$ ). The white precipitate was filtered and washed with ethanol. Solution of hydrogen chloride $(5 \mathrm{M}, 1 \mathrm{~mL})$ was added to the filtrate. The precipitate was filtered and wsahed with ethanol. The filtrate was evaporated in vacuo, and the pure $\left(S_{\mathrm{a}}\right)$-13.HCl was obtained as a solid.

$\left(\boldsymbol{S}_{\mathrm{a}}\right)$-13.HCl. Pale brown solid, yield 95\%, $0.36 \mathrm{~g}, \mathrm{mp}: 195-196{ }^{\circ} \mathrm{C}$ (decomp.), $[\alpha]_{\mathrm{D}}^{25}-159.2(c$ 1.0; EtOH); IR (KBr, $\left.v_{\max }, \mathrm{cm}^{-1}\right): 1662$ (amide C=O). ${ }^{1} \mathrm{H}$ NMR (MeOD, $\left.500 \mathrm{MHz}\right) \delta_{H} 7.96(\mathrm{~d}$, $J_{\mathrm{HH}} 7.5 \mathrm{~Hz}, 1 \mathrm{H}$, phenyl), 7.87 (d, $J_{\mathrm{HH}} 8.1 \mathrm{~Hz}, 1 \mathrm{H}$, phenyl), 7.75 (t, $J_{\mathrm{HH}} 7.8 \mathrm{~Hz}, 1 \mathrm{H}$, phenyl), 6.92 (s, 1H, $\alpha-\mathrm{H}$ pyrrole), $6.75-6.68$ (m, 1H, $\beta^{\prime}-\mathrm{H}$ pyrrole), 6.43 (t, $J_{\mathrm{HH}} 3.3 \mathrm{~Hz}, 1 \mathrm{H}, \beta-\mathrm{H}$ pyrrole), $4.03\left(\mathrm{~d}, J_{\mathrm{HH}} 13.2 \mathrm{~Hz}, 1 \mathrm{H}, \mathrm{PhCH}_{2}-\mathrm{N}\right.$ ), 3.86 (br. s, $\left.1 \mathrm{H}, \mathrm{CH}_{2} \mathrm{CH}_{3}\right), 3.67$ (d, $J_{\mathrm{HH}} 13.2 \mathrm{~Hz}, 1 \mathrm{H}$, $\mathrm{PhCH}_{2}-\mathrm{N}$ ), 3.51 (br. s, $1 \mathrm{H}, \mathrm{CH}_{2} \mathrm{CH}_{3}$ ), $3.43-3.13$ (m, $2 \mathrm{H}, \mathrm{CH}_{2} \mathrm{CH}_{3}$ ), 1.29 (s, 3H, $\left.\mathrm{CH}_{2} \mathrm{CH}_{3}\right), 0.99$ $\left(\mathrm{s}, 3 \mathrm{H}, \mathrm{CH}_{3}\right) \cdot{ }^{13} \mathrm{C} \mathrm{NMR}(\mathrm{MeOD}, 75 \mathrm{MHz}) \delta_{C} 165.0(\mathrm{C}=\mathrm{O}), 139.3\left(\mathrm{~d}, J_{\mathrm{CF}} 1,7 \mathrm{~Hz}\right.$, phenyl), 136.2 (phenyl), 136.0 (phenyl), 131.4 (phenyl), 129.4 (q, $J_{\mathrm{CF}} 30.6 \mathrm{~Hz}$, phenyl)), 129.2 ( $\alpha$-C pyrrole), 129.1 ( $\alpha^{\prime}-\mathrm{C}$ pyrrole), 128.9 (q, $J_{\mathrm{CF}} 5.2 \mathrm{~Hz}$, phenyl)), 124.4 (q, $\left.J_{\mathrm{CF}} 273.3 \mathrm{~Hz}, \mathrm{CF}_{3}\right), 113.9\left(\beta^{\prime}-\mathrm{C}\right.$ pyrrole), 110.6 ( $\beta$-C pyrrole), $44.6\left(\mathrm{PhCH}_{2}-\mathrm{N}, 40.7\left(\mathrm{CH}_{2} \mathrm{CH}_{3}\right), 39.7\left(\mathrm{CH}_{2} \mathrm{CH}_{3}\right), 14.5\left(\mathrm{CH}_{2} \mathrm{CH}_{3}\right)\right.$, $12.3\left(\mathrm{CH}_{2} \mathrm{CH}_{3}\right) .{ }^{19} \mathrm{~F}$ NMR (MeOD, $\left.282 \mathrm{MHz}\right) \delta-61.9$ (s). HRMS (ESI) $\mathrm{m} / \mathrm{z}$ calcd for $\mathrm{C}_{17} \mathrm{H}_{21} \mathrm{~F}_{3} \mathrm{~N}_{3} \mathrm{O}\left[(\mathrm{M}+\mathrm{H})^{+}\right]: 340.1637$, found 340.1648 .

$\left(S_{\mathrm{a}}\right)$-1-[3,5-Bis(trifluoromethyl)phenyl]-3-[2-[2-[(diethylamino)methyl]-1H-pyrrol-1-yl]-3(trifluoromethyl)benzyl]thiourea $\left(\left(\boldsymbol{S}_{\mathbf{a}}\right)-\mathbf{2 a}\right)$. Compound $\left(S_{\mathrm{a}}\right)-\mathbf{1 3} \cdot \mathrm{HCl}(0.7 \mathrm{mmol}, 0.26 \mathrm{~g})$ was dissolved in dichloromethane $(3 \mathrm{ml})$ and solution of sodium hydroxide (1M, $1.5 \mathrm{ml})$ was added. The phases was separated, the aqueous phase was washed with dichloromethane $(2 \times 3 \mathrm{ml})$. The collected organic phase was dried over sodium sulfate and concentrated under reduce pressure. The residue was dissolved in dry toluene $(3 \mathrm{~mL})$ under nitrogen atmosphere and borane dimethylsulfide complex $(2.8 \mathrm{mmol}, 0.27 \mathrm{~mL})$ was added dropwise. The mixture was stirred for 2 days at $60^{\circ} \mathrm{C}$. The formation of the product was monitored by TLC (hexane/ethyl acetate $=$ $1 / 1)$. Methanol $(2 \mathrm{~mL})$ was added dropwise to decompose the excess of borane at room temperature. After the reaction was completed the solvent was evaporated in vacuo and the residue was dissolved in methanol $(3 \mathrm{~mL})$. Sodium hydroxide $(8.4 \mathrm{mmol}, 0.34 \mathrm{~g})$ was added into it, and the mixture was stirred for 5 days at $50{ }^{\circ} \mathrm{C}$. The solvent was evaporated in vacuo, then solution of hydrogen chloride $(5 \mathrm{M}, 3.5 \mathrm{~mL})$ and diethyl ether $(4 \mathrm{~mL})$ was added. After stirring $15 \mathrm{~min}$ the aqueous phase was separated. The collected organic phase was washed with water $(2 \times 3 \mathrm{~mL})$. Sodium hydroxide $(30,0 \mathrm{mmol}, 1.20 \mathrm{~g})$ and diethyl ether $(5 \mathrm{~mL})$ was added to the collected aqueous phase and was extracted with diethyl ether $(3 \times 5 \mathrm{ml})$. The collected organic phase was dried over sodium sulfate an concentrated under reduced pressure. The residue (crude $\left(S_{\mathrm{a}}\right)$-14) was dissolved in dry dichloromethane $(3 \mathrm{~mL})$ and 3,5-bis(trifluoromethyl)phenyl isothiocyanate $(0.7 \mathrm{mmol}, 128 \mu \mathrm{L})$ was added. The reaction mixture was stirred for $30 \mathrm{~min}$. The organic solvent was evaporated in vacuo. The residue was purified by flash chromatography.

$\left(\boldsymbol{S}_{\mathrm{a}}\right)$-2a. Colorless oil, yield 52\%, $0.22 \mathrm{~g},[\alpha]_{\mathrm{D}}^{25}-165.5$ (c 2.2; $\left.\mathrm{CHCl}_{3}\right)$, ee >99\%; HPLC: Phenomenex Lux Cellulose-2 column, eluent $n$-hexane/ethanol $=98 / 2,0,8 \mathrm{~mL} / \mathrm{min}$, uv detector $222 \mathrm{~nm}, 20{ }^{\circ} \mathrm{C}, \mathrm{t}_{(S)}: 14.5 \mathrm{~min}, \mathrm{t}_{(R)}: 13.5 \mathrm{~min}$; $\mathrm{IR}\left(\mathrm{KBr}, v_{\max }, \mathrm{cm}^{-1}\right): 1279(\mathrm{C}=\mathrm{S}) .{ }^{1} \mathrm{H} \mathrm{NMR}\left(\mathrm{CDCl}_{3}\right.$, 
$500 \mathrm{MHz}) \delta_{H} 8.63(\mathrm{~s}, 1 \mathrm{H}, \mathrm{NH}), 8.01\left(\mathrm{~d}, J_{\mathrm{HH}} 7.5 \mathrm{~Hz}, 1 \mathrm{H}, \mathrm{NH}\right), 7.79\left(\mathrm{~s}, 2 \mathrm{H}\right.$, phenyl), $7.76\left(\mathrm{~d}, J_{\mathrm{HH}}\right.$ $7.5 \mathrm{~Hz}, 1 \mathrm{H}$, phenyl), 7.65 (s, 1H, phenyl), 7.59 (t, $J_{\mathrm{HH}} 7.8 \mathrm{~Hz}, 1 \mathrm{H}$, phenyl), 7.38 (s, 1H, phenyl), $6.63\left(\mathrm{~s}, 1 \mathrm{H}, \alpha-\mathrm{H}\right.$ pyrrole), $6.24\left(\mathrm{~s}, 2 \mathrm{H}, \beta+\beta^{\prime}-\mathrm{H}\right.$ pyrrole), $5.43-5.08\left(\mathrm{~m}, 1 \mathrm{H}\right.$, phenyl- $\left.\mathrm{CH}_{2}-\mathrm{N}\right), 3.82$ $\left(\mathrm{d}, J_{\mathrm{HH}} 14.0 \mathrm{~Hz}, 1 \mathrm{H}\right.$, pyrrole-CH$\left.-\mathrm{CH}\right), 3.19\left(\mathrm{~d}, J_{\mathrm{HH}} 14.5 \mathrm{~Hz}, 1 \mathrm{H}\right.$, phenyl- $\left.\mathrm{CH}_{2}-\mathrm{N}\right), 3.12\left(\mathrm{~d}, J_{\mathrm{HH}} 14.0\right.$ $\mathrm{Hz}, 1 \mathrm{H}$, pyrrole- $\left.\mathrm{CH}_{2}-\mathrm{N}\right), 2.52\left(\mathrm{sex}, J_{\mathrm{HH}} 7.0 \mathrm{~Hz}, 2 \mathrm{H}, \mathrm{CH}_{2} \mathrm{CH}_{3}\right), 2.33\left(\mathrm{sex}, J_{\mathrm{HH}} 7.0 \mathrm{~Hz}, 2 \mathrm{H}\right.$, $\left.\mathrm{CH}_{2} \mathrm{CH}_{3}\right), 0.73\left(\mathrm{t}, J_{\mathrm{HH}} 7.0 \mathrm{~Hz}, 6 \mathrm{H}, \mathrm{CH}_{2} \mathrm{CH}_{3}\right) .{ }^{13} \mathrm{C} \mathrm{NMR}\left(\mathrm{CDCl}_{3}, 75 \mathrm{MHz}\right) \delta_{C} 181.3(\mathrm{C}=\mathrm{S}), 140.3$ (phenyl), 141.0 (phenyl), 136.0 (d, $J_{\mathrm{CF}} 1.5 \mathrm{~Hz}$, phenyl)), 134.2 (br. s, 2C, phenyl)), 132.4 (q, $J_{\mathrm{CF}}$ $33.7 \mathrm{~Hz}, 2 \mathrm{C}$, phenyl)), 130.6 (phenyl), 129.7 (phenyl), 129.0 (q, $J_{\mathrm{CF}} 30.3 \mathrm{~Hz}$, phenyl)), 126.3 (q, $J_{\mathrm{CF}} 5.2 \mathrm{~Hz}$, phenyl)), 123.9 (2C, phenyl+a-C pyrrole)), 122.9 (q, $\left.J_{\mathrm{CF}} 272.9 \mathrm{~Hz}, 2 \mathrm{C}, \mathrm{CF}_{3}\right), 122.8$ $\left(\mathrm{q}, J_{\mathrm{CF}} 272.3 \mathrm{~Hz}, \mathrm{CF}_{3}\right), 118.9$ (sep, $J_{\mathrm{CF}} 3.8 \mathrm{~Hz}, \alpha^{\prime}-\mathrm{C}$ pyrrole), 111.4 ( $\beta^{\prime}-\mathrm{C}$ pyrrole), 108.9 ( $\beta-\mathrm{C}$ pyrrole), $46.6\left(2 \mathrm{C}, \mathrm{CH}_{2} \mathrm{CH}_{3}\right), 46.2,\left(\mathrm{CH}_{2}\right), 43.4,\left(\mathrm{CH}_{2}\right), 10.0\left(2 \mathrm{C}, \mathrm{CH}_{2} \mathrm{CH}_{3}\right) .{ }^{19} \mathrm{~F} \mathrm{NMR}\left(\mathrm{CDCl}_{3}\right.$, $282 \mathrm{MHz}) \delta_{F}-60.8(\mathrm{~s}, 3 \mathrm{~F}),-63.0(\mathrm{~s}, 6 \mathrm{~F})$. HRMS (ESI) $m / z$ calcd for $\mathrm{C}_{26} \mathrm{H}_{26} \mathrm{~F}_{9} \mathrm{~N}_{4} \mathrm{~S}\left[(\mathrm{M}+\mathrm{H})^{+}\right]$: 597.1734 , found 597.1744 .

$\left(S_{\mathrm{a}}\right)$-3-[2-( $N, N$-diethylaminomethyl-1 $H$-pyrrol-1-yl)-3-(trifluoromethyl)benzyl]-1-phenyl-

thiourea $\left(\left(\boldsymbol{S}_{\mathbf{a}}\right)-\mathbf{2 b}\right)$. This was prepared analogously to $\left(S_{\mathrm{a}}\right)$-2a but phenyl isothiocyanate $(0.7$ mmol, $84 \mu \mathrm{L}$ ) was used instead of 3,5-bis(trifluoromethyl)phenyl isothiocyanate.

$\left(\boldsymbol{S}_{\mathrm{a}}\right)$-2b. Colorless oil, yield 58\%, $0.19 \mathrm{~g} ;[\alpha]_{\mathrm{D}}^{25}-52.9$ (c $\left.0.42 ; \mathrm{CHCl}_{3}\right)$, ee >99\%; HPLC: Phenomonex Lux Cellulose-2 column $(5 \mu \mathrm{m}, 250 \times 4.6 \mathrm{~mm})$, eluent $\mathrm{n}$-hexane/ethanol = 80:20, $0.8 \mathrm{ml} / \mathrm{min}$, uv detector: $222 \mathrm{~nm}, 20{ }^{\circ} \mathrm{C}, \mathrm{t}_{(S)}=14.5 \mathrm{~min}, \mathrm{t}_{(R)}=13.5 \mathrm{~min}$; $\mathrm{IR}\left(\mathrm{KBr}, v_{\max }, \mathrm{cm}^{-1}\right)$ : $1318(\mathrm{C}=\mathrm{S}) .{ }^{1} \mathrm{H}-\mathrm{NMR}\left(\mathrm{CDCl}_{3}, 300 \mathrm{MHz}\right) \delta_{H}: 7.95\left(1 \mathrm{H}, \mathrm{d}, J_{\mathrm{HH}} 7.8 \mathrm{~Hz}, \mathrm{NH}\right), 7.69\left(2 \mathrm{H}, \mathrm{d}, J_{\mathrm{HH}} 7.5\right.$ $\mathrm{Hz}$, phenyl), $7.55\left(1 \mathrm{H}, \mathrm{t}, J_{\mathrm{HH}} 7.8 \mathrm{~Hz}\right.$, phenyl), $7.38\left(2 \mathrm{H}, \mathrm{t}, J_{\mathrm{HH}} 7.5 \mathrm{~Hz}\right.$, phenyl), $7.29\left(1 \mathrm{H}, \mathrm{t}, J_{\mathrm{HH}}\right.$ $7.4 \mathrm{~Hz}$, phenyl), 7.18 (2H, d, $J_{\mathrm{HH}} 7.5 \mathrm{~Hz}$, phenyl), $6.79(1 \mathrm{H}, \mathrm{s}, \mathrm{NH}), 6.49$ (1H, s, pyrrole), 6.11 $\left(2 \mathrm{H}, \mathrm{m}\right.$, pyrrole), $4.97\left(1 \mathrm{H}, \mathrm{d}, J_{\mathrm{HH}} 13.8 \mathrm{~Hz}, \mathrm{CH}_{2}\right), 4.48\left(1 \mathrm{H}, \mathrm{d}, J_{\mathrm{HH}} 15.0 \mathrm{~Hz}, \mathrm{CH}_{2}\right), 3.10(1 \mathrm{H}, \mathrm{d}$, $\left.J_{\mathrm{HH}} 14.1 \mathrm{~Hz}, \mathrm{CH}_{2}\right), 2.95\left(1 \mathrm{H}, \mathrm{d}, J_{\mathrm{HH}} 14.1 \mathrm{~Hz}, \mathrm{CH}_{2}\right), 2.15\left(2 \mathrm{H}, \mathrm{sx}, J_{\mathrm{HH}} 7.0 \mathrm{~Hz}, \mathrm{CH}_{2} \mathrm{CH}_{3}\right), 2.04$ $\left(2 \mathrm{H}, \mathrm{sx}, J_{\mathrm{HH}} 7.0 \mathrm{~Hz}, \mathrm{CH}_{2} \mathrm{CH}_{3}\right), 0.49\left(6 \mathrm{H}, \mathrm{t}, J_{\mathrm{HH}} 7.0 \mathrm{~Hz}, \mathrm{CH}_{2} \mathrm{CH}_{3}\right) .{ }^{13} \mathrm{C}-\mathrm{NMR}\left(\mathrm{CDCl}_{3}, 75 \mathrm{MHz}\right)$ $\delta_{C}: 181.6(\mathrm{C}=\mathrm{S}), 141.1$ (phenyl), 136.3 (phenyl), 135.8 (phenyl), 133.3 (phenyl), 131.1 (phenyl), 130.0 (2C, phenyl), 129.1 (phenyl), 128.7 (q, $J_{\mathrm{CF}} 29.9 \mathrm{~Hz}$, phenyl), 127.4 (phenyl), 125.8 (2C, phenyl $+\alpha-C$ pyrrole), 125.6 (q, $J_{\mathrm{CF}} 4.9 \mathrm{~Hz}$, phenyl), 123.6 ( $\alpha^{\prime}-\mathrm{C}$ pyrrole), $123.0\left(\mathrm{q}, J_{\mathrm{CF}} 272.2 \mathrm{~Hz}\right.$, $\left.\mathrm{CF}_{3}\right), 110.7$ ( $\beta^{\prime}$-C pyrrole), 108.3 ( $\beta$-C pyrrole), $46.6\left(\mathrm{CH}_{2}\right), 46.3\left(2 \mathrm{C}, \mathrm{CH}_{2} \mathrm{CH}_{3}\right), 44.1\left(\mathrm{CH}_{2}\right)$, $10.4\left(2 \mathrm{C}, \mathrm{CH}_{2} \mathrm{CH}_{3}\right) .{ }^{19} \mathrm{~F}-\mathrm{NMR}\left(\mathrm{CDCl}_{3}, 282 \mathrm{MHz}\right) \delta_{\mathrm{F}}$ : -60.6 (s). HRMS (ESI) $\mathrm{m} / z$ calcd for $\mathrm{C}_{24} \mathrm{H}_{27} \mathrm{~F}_{3} \mathrm{~N}_{4} \mathrm{~S}\left[(\mathrm{M}+\mathrm{H})^{+}\right]$: 461.1987, found 461.1991.

General procedure for the addition of 1,3-dicarbonyl-compounds to $\beta$-nitrostyrene. $\beta$ Nitrostyrene $(0.4 \mathrm{mmol}, 59.6 \mathrm{mg})$ was dissolved in the corresponding solvent $(60 \mu \mathrm{L})$, the chiral catalyst was added at the corresponding temperature. After stirring 10 min dibenzoylmethane $(1.0 \mathrm{mmol}, 224.2 \mathrm{mg})$ or acetylacetone $(1.0 \mathrm{mmol}, 102: 7 \mu \mathrm{l})$ was added. The mixture was stirred for a week. The solvent was evaporated in vacuo, and the residue was purified by flash chromatography.

2-(2-Nitro-1-phenylethyl)-1,3-diphenylpropane-1,3-dione (17). ${ }^{25}{ }^{1} \mathrm{H} \mathrm{NMR}\left(500 \mathrm{MHz}, \mathrm{CDCl}_{3}\right)$ $\delta 7.88-7.85(\mathrm{~m}, 2 \mathrm{H}), 7.80-7.76(\mathrm{~m}, 2 \mathrm{H}), 7.57-7.46(\mathrm{~m}, 2 \mathrm{H}), 7.42-7.31(\mathrm{~m}, 4 \mathrm{H}), 7.25-7.10$ $(\mathrm{m}, 5 \mathrm{H}), 5.85\left(\mathrm{~d}, J_{\mathrm{HH}} 8.0 \mathrm{~Hz}, 1 \mathrm{H}\right), 4.99\left(\mathrm{~d}, J_{\mathrm{HH}} 6.9 \mathrm{~Hz}, 2 \mathrm{H}\right), 4.63$ (q, $\left.J_{\mathrm{HH}} 7.2 \mathrm{~Hz}, 1 \mathrm{H}\right)$. Yield and 
ee was determined by HPLC analysis using Phenomenex Lux Cellulose-1 column, eluent $n$ hexane/ethanol $=80 / 20,0,8 \mathrm{~mL} / \mathrm{min}$, uv detector: $250 \mathrm{~nm}, 2{ }^{\circ} \mathrm{C}$, $\mathrm{t}_{\text {major }}: 11.28 \mathrm{~min}, \mathrm{t}_{\text {minor }}: 15.26$ $\min$.

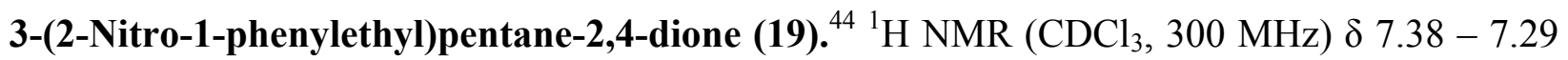
$(\mathrm{m}, 3 \mathrm{H}), 7.22-7.19(\mathrm{~m}, 2 \mathrm{H}), 4.69-4.58(\mathrm{~m}, 2 \mathrm{H}), 4.38\left(\mathrm{~d}, J_{\mathrm{HH}} 10.8 \mathrm{~Hz}, 1 \mathrm{H}\right), 4.30-4.18(\mathrm{~m}$, $1 \mathrm{H}), 2.29(\mathrm{~s}, 3 \mathrm{H}), 1.94(\mathrm{~s}, 3 \mathrm{H})$. Yield and ee was determined by HPLC analysis using Phenomenex Lux Amylose-2 column, eluent $n$-hexane/ethanol = 85/15, $0.8 \mathrm{~mL} / \mathrm{min}$, uv detector: $222 \mathrm{~nm}, 20^{\circ} \mathrm{C}$, $\mathrm{t}_{\text {major }}: 17.39 \mathrm{~min}, \mathrm{t}_{\text {minor }}: 19.31 \mathrm{~min}$.

\section{Acknowledgements}

The authors are gratefully acknowledge the Hungarian Scientific Research Fund (OTKA K 104528) for their financial support. This work is also connected to the scientific program of the "Development of quality-oriented and harmonized $\mathrm{R}+\mathrm{D}+\mathrm{I}$ strategy and functional model at BME" project, supported by the New Széchenyi Plan (Project ID: TÁMOP-4.2.1/B-09/1/KMR2010-0002).

\section{References}

1. Tsakos, M.; Kokotos, Ch. G. Tetrahedron 2013, 69, 10199. http://dx.doi.org/10.1016/j.tet.2013.09.080

2. $\mathrm{Pu}, \mathrm{X} .-\mathrm{W} . ;$ Peng, F.-Z.; Zhang, H.-B.; Shao, Z.-H. Tetrahedron 2010, 66, 3655. http://dx.doi.org/10.1016/j.tet.2010.03.081

3. Sigman, M. S.; Jacobsen, E. N. J. Am. Chem. Soc. 1998, 120, 4901. http://dx.doi.org/10.1021/ja980139y

4. Sigman, M. S.; Vachal, P.; Jacobsen, E. N. Angew. Chem. 2000, 112, 1336. http://dx.doi.org/10.1002/(SICI)1521-3757(20000403)112:7<1336::AIDANGE1336>3.0.CO;2-Z

5. Vachal, P.; Jacobsen, E. N. J. Am. Chem. Soc. 2002, 124, 10012. http://dx.doi.org/10.1021/ja027246j

6. Connon, S. J. Synlett 2009, 354.

7. Connon, S. J. Chem. Commun. 2008, 2499.

8. Doyle, A. G.; Jacobsen, E. N. Chem. Rev. 2007, 107, 5713. http://dx.doi.org/10.1021/cr068373r

9. Zhang, Z.; Schreiner, P. R. Chem. Soc. Rev. 2009, 38, 1187. http://dx.doi.org/10.1039/b801793j

10. Cao, Y.; Lai, Y.; Wang, X.; Li, Y.; Xiao, W. Tetrahedron Lett. 2007, 48, 21. http://dx.doi.org/10.1016/j.tetlet.2006.11.037 
11. Sohtome, Y.; Hashimoto, Y.; Nagasawa, K. Adv. Synth. Catal. 2005, 347, 1643.

http://dx.doi.org/10.1002/adsc.200505148

12. Chang, Y.; Yang, J.; Dang, J.; Xue, Y. Synlett 2007, 2283. http://dx.doi.org/10.1055/s-2007-984916

13. Tsogoeva, S. B.; Yalalov, D. A.; Hateley, M. J.; Weckbecker, C.; Huthmacher, K. Eur. J. Org. Chem. 2005, 4995.

http://dx.doi.org/10.1002/ejoc.200500420

14. Yeboah, E. M. O.; Yeboah, S. O.; Singh, G. S. Tetrahedron 2011, 67, 1725. http://dx.doi.org/10.1016/j.tet.2010.12.050

15. Sakthivel, K.; Notz, W.; Bui, T.; Barbas III, C. F. J. Am. Chem. Soc. 2001, 123, 5260. http://dx.doi.org/10.1021/ja010037z

16. Wang, Y.; Liu, X.-F.; Deng, L. J. Am. Chem. Soc. 2006, 128, 3928. http://dx.doi.org/10.1021/ja060312n

17. Yoon T. P.; Jacobsen, E. N. Science 2003, 299, 1691. http://dx.doi.org/10.1126/science.1083622

18. Hoffmann, H. M. R.; Frackenpohl, J. Eur. J. Org. Chem. 2004, 4293. http://dx.doi.org/10.1002/ejoc.200400294

19. Wang, J.; Li, H.; Yu, X.; Zu, L.; Wang, W. Organic Lett. 2005, 7, 4293. http://dx.doi.org/10.1021/o1051822+

20. Galzerano, P.; Bencivenni, G.; Pesciaioli, F.; Mazzanti, A.; Giannichi, B.; Sambri, L.; Bartoli, G.; Melchiorre, P. Chem. Eur. J. 2009, 15, 7846. http://dx.doi.org/10.1002/chem.200802466

21. Tan, B.; Candeias, N. R.; Barbas III, C. F. Nat. Chem. 2011, 3, 473.

22. Sohtome, Y.; Nagasawa, K. Chem. Commun. 2012, 48, 7777. http://dx.doi.org/10.1039/c2cc31846f

23. Wang, C.-J.; Zhang, Z.-H.; Dong, X.-Q.; Wu, X.-J. Chem. Commun. 2008, 1431. http://dx.doi.org/10.1039/b718949d

24. Malerich, J. P.; Hagihara, K.; Rawal, V. H. J. Am. Chem. Soc. 2008, 130, 14416. http://dx.doi.org/10.1021/ja805693p

25. Tan, B.; Zhang, X.; Chua, P. J.; Zhong, G. Chem. Commun. 2009, 779. http://dx.doi.org/10.1039/B813915F

26. Liu, B.; Han, X.; Dong, Z.; Lv, H.; Zhou, H.-B.; Dong, C. Tetrahedron: Asymmetry 2013, 24, 1276. http://dx.doi.org/10.1016/j.tetasy.2013.08.010

27. Isik, M.; Unver, M. Y.; Tanyeli, C. J. Org. Chem. 2015, 80, 828. http://dx.doi.org/10.1021/jo5022597

28. Faigl, F.; Erdélyi, Zs.; Deák, Sz.; Nyerges, M.; Mátravölgyi, B. Tetrahedron Lett. 2014, 55, 6891.

http://dx.doi.org/10.1016/j.tetlet.2014.10.101 
29. Mátravölgyi, B.; Kovács, E.; Hegedüs, L.; Jászay, Zs.; Thurner, A.; Deák, Sz.; Erdélyi, Zs.; Pham, T. S.; Gönczi, K.; Sólyom, Sz.; Tőke, L.; Faigl, F. Periodica Polytechnica Chemical Engineering 2015, 59, 38.

30. Faigl, F.; Deák, Sz.; Erdélyi, Zs.; Holzbauer, T.; Czugler, M.; Nyerges, M.; Mátravölgyi, B. Chirality, 2015, 27, 216. http://dx.doi.org/10.1002/chir.22415

31. Faigl, F.; Mátravölgyi, B.; Holczbauer, T.; Czugler, M.; Madarász, J. Tetrahedron: Asymmetry 2011, 22, 1879. http://dx.doi.org/10.1016/j.tetasy.2011.10.021

32. Faigl, F.; Mátravölgyi, B.; Szöllősy, Á.; Czugler, M.; Tárkányi, G.; Vékely, K.; Kubinyi, M. Chirality 2012, 24, 532. http://dx.doi.org/10.1002/chir.22049

33. Faigl, F.; Erdélyi, Zs.; Nyerges, M.; Mátravölgyi, B. Tetrahedron: Asymmetry 2015, 26, 738. http://dx.doi.org/10.1016/j.tetasy.2015.06.004

34. Faigl, F.; Tárkányi, G.; Fogassy, K.; Tepfenhart, D.; Thurner, A. Tetrahedron 2008, 64, 1371. http://dx.doi.org/10.1016/j.tet.2007.11.058

35. Boyd, G. V.; Monteil, R. L. J. Chem. Soc. Perkin Trans. 1 1978, 11, 1338. http://dx.doi.org/10.1039/p19780001338

36. Yuan, Y.; Bai, L.; Nan, J.; Liu, J.; Luan, X. Org. Lett. 2014, 16, 4316. http://dx.doi.org/10.1021/o15020587

37. Oh, J-S.; Lee, J-W.; Ryu, T. H.; Lee, J. H.; Song, C. E. Org. Biomol. Chem., 2012, 10, 1052. http://dx.doi.org/10.1039/C1OB06629C

38. Jang, H. B.; Rho, H. S.; Oh, J. S.; Nam, E. H.; Park, S. E.; Baea, H. Y.; Song, C. E. Org. Biomol. Chem. 2010, 8, 3918. http://dx.doi.org/10.1039/c0ob00047g

39. CrystalClear SM 1.4.0 (Rigaku/MSC Inc., 2008).

40. NUMABS: Higashi, T. (1998), rev. 2002. (Rigaku/MSC Inc.)

41. Sheldrick, G. M. Acta Cryst. 2008, A64, 112. http://dx.doi.org/10.1107/S0108767307043930

42. PLATON: Spek, A. L. J. Appl.Cryst. 2003, 36, 7.

43. S. Parsons, H. Flack, Acta Cryst. 2004, A60, s61. http://dx.doi.org/10.1107/S0108767304098800

44. Almasi D.; Alonso, D. A.; Gomez-Bengoa, E.; Najera, C. J. Org. Chem. 2009, 74, 6163. http://dx.doi.org/10.1021/jo9010552 